\title{
The Neuroanatomical Axis for Control of Energy Balance
}

\author{
Harvey J . Grill and J oel M. Kaplan \\ Graduate Groups of Psychology and Neuroscience, University of Pennsylvania, \\ 3815 Walnut Street, Philadelphia, Pennsylvania 19104
}

\begin{abstract}
The hypothalamic feeding-center model, articulated in the 1950s, held that the hypothalamus contains the interoceptors sensitive to blood-borne correlates of available or stored fuels as well as the integrative substrates that process metabolic and visceral afferent signals and issue commands to brainstem mechanisms for the production of ingestive behavior. A number of findings reviewed here, however, indicate that sensory and integrative functions are distributed across a central control axis that includes critical substrates in the basal forebrain as well as in the caudal brainstem. First, the interoceptors relevant to energy balance are distributed more widely than had been previously thought, with a prominent brainstem complement of leptin and insulin receptors, glucose-sensing mechanisms, and neuropeptide mediators. The physiological relevance of this multiple representation is suggested by the demonstration that similar behavioral effects can be obtained independently by stimulation of respective forebrain and brainstem subpopulations of the same receptor types (e.g., leptin, $\mathrm{CRH}$, and melanocortin). The classical hypothalamic model is also challenged by the integrative achievements of the chronically maintained, supracollicular decerebrate rat. Decerebrate and neurologically intact rats show similar discriminative responses to taste stimuli and are similarly sensitive to intake-inhibitory feedback from the gut. Thus, the caudal brainstem, in neural isolation from forebrain influence, is sufficient to mediate ingestive responses to a range of visceral afferent signals. The decerebrate rat, however, does not show a hyperphagic response to food deprivation, suggesting that interactions between forebrain and brainstem are necessary for the behavioral response to systemic/ metabolic correlates of deprivation in the neurologically intact rat. At the same time, however, there is evidence suggesting that hypothalamic-neuroendocrine responses to fasting depend on pathways ascending from brainstem. Results reviewed are consistent with a distributionist (as opposed to hierarchical) model for the control of energy balance that emphasizes: (i) control mechanisms endemic to hypothalamus and brainstem that drive their unique effector systems on the basis of local interoceptive, and in the brainstem case, visceral, afferent inputs and (ii) a set of uni- and bidirectional interactions that coordinate adaptive neuroendocrine, autonomic, and behavioral responses to changes in metabolic status. KEY WoRDS: feeding behavior; leptin; glucose sensing; decerebrate; neuropeptide; hypothalamic model; caudal brainstem; energy balance. o 2002 Elsevier Science
\end{abstract}

\section{INTRODUCTION}

Research into the neural control of energy homeostasis has been profoundly energized by a number of findings that have emerged over the past few yearsfrom the discovery of leptin and its central receptors to the identification of a variety of important peptide mediators and their interactions. For better or 
worse, the findings have been cast in relation to the century-old hypothalamocentric view of the central feeding control system. At the present time, however, we can reflect on a slower process that is arguably displacing this centrist perspective. It now seems more reasonable to speak of a central control axis for energy balance that entails ventral forebrain substrates for neuroendocrine control on the one hand and caudal brainstem networks for behavioral organization and autonomic reflex control, on the other.

The essential features of the hypothalamic model were articulated in a landmark review by Eliot Stellar in 1954 (178). There was a representation in the model for the caudal brainstem as the seat of motor and premotor networks for ingestive behavior. These networks, however, were not seen as autonomous; they were, rather, subject to command control by hypothalamic integrators sitting on top of the control hierarchy. For the orchestration of responses appropriate to prevailing conditions, the hypothalamus would require sensory input from a variety of sources, one important source being central interoceptors sensitive to blood-borne correlates of metabolic state. These interoceptors were seen as contained within the hypothalamus proper. Another important source of sensory information relevant to feeding control is derived from gustatory and gastrointestinal receptors. It was well known that such visceral sensory feedback is received in the dorsal vagal complex of the caudal brainstem, but its behavioral impact was seen as mediated by a long-loop mechanism involving ascending vagal sensory pathways, obligatory processing in the hypothalamus, and descending command.

The model has successfully incorporated important devel opments in the field over the past three decades. Specific interoceptive mechanisms, sensitive to glucose metabolism and body fat reserves, were identified and localized to hypothalamic substrates. On the output side, increased emphasis has been placed on vagal efferent systems which exert dramatic effects on fuel metabolism and disposition with respect to utilization versus storage as fat $(10,143)$. Here, as with behavioral control, brainstem premotor and effector systems were seen as subject to descending modulation arising from the hypothalamic sources. Much has been learned about anatomical, neurochemical, and functional relationships among the principal hypothalamic nuclei that mediate interoceptive influence on neuroendocrine output. In parallel, it has become clear that the same neurochemical systems give rise to long projections to autonomic centers in brainstem and spinal cord, with potential for stimulation and inhibition of ingestive behavior. Through this work, the early emphasis on the ventromedial hypothalamus $(\mathrm{VMH})$ and lateral hypothalamus $(\mathrm{LH})$ as principal subcenters of the energy balance control network has expanded to include powerful influences of the paraventricular (PVN), arcuate, and dorsomedial nuclei (e.g., 7, 110, 113, 159). Researchers have achieved a considerable level of resolution about the inner workings of the relevant hypothalamic circuits (e.g., 23, 36, 45, 50, 153, 158), which has been taken as an important development of the single-integrator model of hypothalamic coordination of neuroendocrine, autonomic, and behavioral outputs. 
Other findings, however, are not straightforwardly accommodated by the single-integrator model. One development was derived from a series of experiments demonstrating that the chronically maintained decerebrate rat, with complete high mesencephalic transection, displayed coordinated behavioral responses to gustatory and visceral afferent stimuli $(75,77)$. Whereas the hypothalamic model incorporates a behavior-integrative function, these findings show that contained within the caudal brainstem are integrative mechanisms capable of translating feeding-rel evant sensory information into adaptive responses reminiscent of those obtained in the neurologically intact rat. The decerebrate's response to gastrointestinal and gustatory feedback, the primary controls of ingestive behavior over the short term (e.g., 15, 30, 40, 125, 207), endows it with a semblance of normal meal size control. Most intriguing, it has also become clear in recent years that within the brainstem are interoceptor mechanisms that provide the kind of information underlying control of energy balance over the longer term. The functional significance of these caudal brainstem interoceptors, however, is not yet fully resolved. We do not know, for example, whether they report to hypothalamic command centers as part of a long-loop arrangement or whether they are capable of modulating behavior via circuits endemic to the caudal brainstem. In any event, the demonstrated integrative capacity of the caudal brainstem has the potential to dramatically alter the way we look at the control of proximal effectors and perspectives about ascending, descending, and bidirectional interactions between hypothalamus and caudal brainstem.

\section{INTEROCEPTORS}

Interoceptors, as we use the term, refer to CNS sensors responsive to blood-borne signals correlated with the metabolic state of the animal. A broad range of signals, therefore, would fall under the purview of central interoception, including, for example, adrenal and thyroid hormones whose levels vary with physiological state. For this discussion we restrict our attention to certain interoceptive mechanisms that respond more or less directly to the levels of utilizable or stored fuels. We consider central receptors for leptin and insulin that signal adiposity and cellular mechanisms that endow specialized neurons with sensitivity to extracellular glucose level. For each system, we consider evidence for brainstem as well as hypothalamic interoceptors and ask whether adaptive responses arise from focal stimulation of disparate interoceptor populations.

\section{Leptin}

Recent studies show that adipose tissue produces a circulating peptide hormone called leptin (or OB protein), whose levels vary with fat mass (86, 209). Leptin enters the brain and stimulates leptin receptors (Ob-R) among 
which, according to the weight of current evidence, the long-form receptor (Ob-Rb) is the most important for the effects of leptin on energy balance (1). Changes in leptin level affect behavioral, autonomic, and endocrine mechanisms that govern energy intake, expenditure, and storage (e.g., 4, 31, 131, 204). The discovery of leptin has thereby provided an adiposity feedback signal long sought in models of energy balance (104) and has energized research on food intake, obesity, and diabetes. The focus on leptin has also directed attention to important peptide mediators (see below) that along with Ob-Rb are found abundantly in the hypothalamus. The presence of these elements in hypothalamic nuclei, the systematic effects of leptin treatment on orexigenic and anorexigenic neuropeptide expression, and the historical emphasis on hypothalamic control of energy balance have left little impetus to explore possible extrahypothalamic mechanisms of leptin action.

In the earliest phase of investigation, experimenters did not expect to find long-form leptin receptors in the caudal brainstem; at the very least, they were not sought after (e.g., 54). Somewhat later, the presence of Ob-Rb in the hindbrain was addressed although the results were not consistent across studies. For example, Mercer et al. (121) described hybridization signal for $\mathrm{Ob}-\mathrm{Rb}$ in the nucleus of the solitary tract (NTS) and parabrachial nucleus (PBN) of the mouse and in the NTS of the rat. There were also reports of leptin receptor immunoreactivity in the medulla, but the specificity of the antibodies used with respect to different receptor isoforms was called into question (165, 169). EImquist et al. (48) examined hybridization signal for Ob-Rb in the NTS and the two other divisions of the dorsal vagal complex [the area postrema (AP) and the dorsal motor nucleus of the vagus (DMX)], but reported that expression was low and inconsistent across animals.

We recently revisited the question of $\mathrm{Ob}-\mathrm{Rb}$ in the caudal brainstem in collaboration with Denis Baskin and Michael Schwartz (see 79). A highly sensitive fluorescence in situ hybridization (FISH) method (20) was used along with an immunocytochemical analysis with a polyclonal antibody specific to human $\mathrm{Ob}-\mathrm{Rb}$ (6). Strong hybridization signal was detected in several caudal brainstem structures implicated in the control of food intake including all three divisions of the dorsal vagal complex (DVC) and the parabrachial nucleus. In addition, Ob-Rb mRNA FISH signal was present in a number of other brainstem areas including hypoglossal, trigeminal, lateral reticular, and cochlear nuclei, locus coeruleus, and inferior olive. The distribution of FISH signal was in agreement with that obtained through the immunocytochemical analysis. (Photomicrographs of the hybridization signal and immunostaining in AP, NTS, and DMX are shown in Fig. 1.) We can conclude that the distribution of $\mathrm{Ob}-\mathrm{Rb}$ of potential relevance to intake control is broader than had been supposed.

It had been shown that direct delivery of leptin to the lateral or third ventricle suppresses food intake up to $24 \mathrm{~h}$ after treatment $(156,192)$. The finding was consistent with the hypothalamic model, but did not rule out the possibility of extrahypothalamic contribution. To explore the plausibility of the hypothesis that $\mathrm{Ob}-\mathrm{Rb}$ in the caudal brainstem contributes to the physiological 

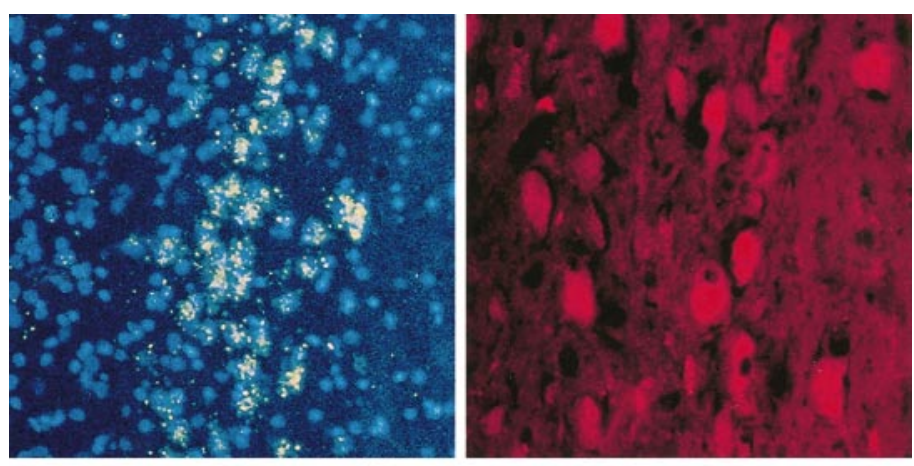

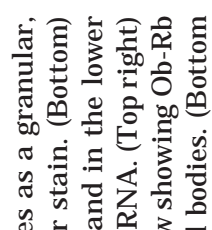

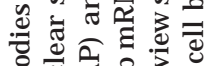

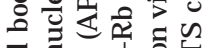
$\overline{\bar{\Theta}}$ 药 $\subseteq$ 눤 ज专专焉 즘

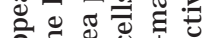

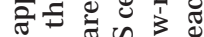

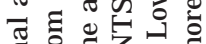

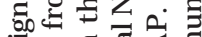

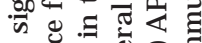
I ज步 ज ए प

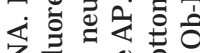
乙这ब 00 थ $\geq$ 뒤 ह 긍 पूँ

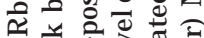

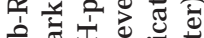
응 눙 $\frac{1}{0}$ 흥 즈동

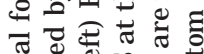
든

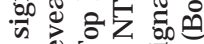
工比的

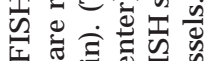

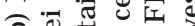
응 元 比离比品 हं 言 vं О 응

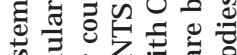

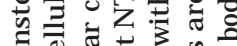
. 立拧

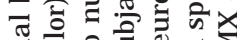
응하의 (0) 0

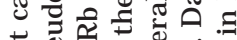

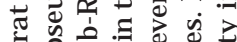
의 $n=$ 두 워 \&

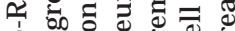
응 응 \&

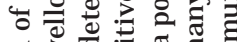

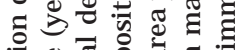

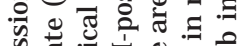
प)

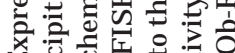

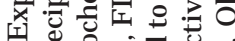
प

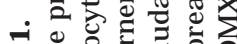

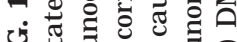
ง

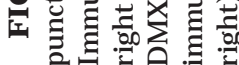


response to leptin, we delivered the peptide to the brainstem (fourth) ventricle and to the hindbrain parenchyma (71). Fourth-intracerebroventricular (icv) leptin significantly reduced food intake 2, 4, and $24 \mathrm{~h}$ after injection and suppressed body weight. We also showed that a leptin dose $(0.1 \mu \mathrm{g})$ that was subthreshold for the icv effect suppressed intake when microinjected unilaterally into the DVC. This observation was important as it supports the presumption that the 4th-icv effect did indeed arise from stimulation of the brainstem parenchyma. The data do not imply that the DVC is the only site at which leptin might act to reduce intake, nor do they challenge the relevance of hypothalamic leptin receptors. To the contrary, we showed dose-response profiles for 4th- and lateral-icv leptin administration that were indistinguishable, suggesting to us that ingestive effects can be triggered independently by respective stimulation of hypothalamic (92) and caudal brainstem Ob-Rb subpopulations.

That the brainstem contains physiologically relevant leptin receptors is further supported by studies of autonomic and endocrine responses. Smedh et al. (169) showed a dose-related suppression of gastric emptying upon leptin delivery to the fourth ventricle that was reversed by subdiaphragmatic vagotomy. Zhou and Schneider (210) reported that leptin administered to the fourth ventricle reversed the fasting-induced blockade of the estrus cycle in hamsters. A number of important issues remain open including (i) whether the feeding, endocrine, and autonomic effects of brainstem leptin administration are triggered by the same or different Ob-Rb subpopulations; (ii) whether the feeding and gastric motility actions are mediated by local versus long-loop (i.e., involving hypothalamus) mechanisms; and (iii) the role of Ob-Rb in brainstem structures not typically associated with the control of energy homeostasis. In any event, these findings and other developments that may be expected in the near future should promote an assimilation by the field of the notion that leptin receptors in the caudal brainstem, stimulated concurrently with hypothalamic receptors under physiological conditions, can play an important role in the control of energy balance.

\section{Insulin}

Levels of insulin, like leptin, vary with adiposity (142) and perform signaling functions pertinent to intake and body weight control. Neither is produced in the brain, and for each, there is a transport mechanism in the capillary endothelium that delivers the hormone to CNS receptors (157). Also like leptin, delivery of insulin to the brain, simulating energy surfeit and elevated adiposity, results in reduction of food intake $(5,203)$. The contribution of brain insulin receptors to energy balance was recently highlighted by the finding that mice lacking brain insulin receptors are hyperphagic and obese (27). Insulin has a complex physiological profile; its presumptive role as an adiposity signal is distinct from its mobilization in relation to meal taking. And there should be no confusion between intake suppression relating to insulin's adi- 
posity signaling function and the hyperphagia that is secondary to the acute hypoglycemia attending systemic administration of high-dose insulin.

The intake-suppressive effects obtained with 3rd-icv administration implicate hypothalamic insulin receptors as a relevant target for this putative adiposity signal. Expression of insulin receptors, however, is not limited to the hypothalamus. Insulin receptors have also been identified in the DVC and a number of other caudal brainstem sites (e.g., 189, 193). Like hypothalamic neurons bearing insulin receptors, those in the brainstem also are endowed with intracellular signaling substrates including insulin receptor substrate-1 and phosphatidylinositol 3-kinase (61). The consequences of brainstem insulin signaling to intake and body weight control have yet to be explored by 4th-icv or brainstem intraparenchymal administration studies. Other than raising the possibility, therefore, little can be said about independent behavioral, autonomic, or endocrine effects arising from stimulation of brainstem insulin receptors or about summative or synergistic interactions between brainstem and hypothalamic insulin-sensitive mechanisms.

\section{Glucose Sensors}

The brain directly senses glucose or correlates of its metabolic action (112). Although all neurons utilize glucose as a fuel, only a subset are held to change electrophysiological activity as a function of glucose level in a manner that may, in turn, affect ingestive, autonomic, and neuroendocrine responses. These glucose-sensing cells, therefore, represent the interoceptive element for the detection of extracellular glucose concentration. There appear to be two populations of such neurons: "glucose-sensitive" cells hyperpolarize, and "glucose-responsive" cells depolarize, with an elevation in extracellular glucose (112). The basis for the response of glucose-responsive neurons is yielding to cellular analysis. Interestingly, similar mechanisms appear to underlie the electrophysiological response of brain glucose-responsive neurons and the insulin secretory response of the pancreatic beta cell (186). For both cell types, increased glucose concentration elevates intracellular ATP, which inhibits ATP-sensitive potassium channels ( $K_{\text {ATP }}$ channels). This, in turn, results in increased intracellular $\mathrm{K}^{+}, \mathrm{Ca}^{2+}$ influx and depolarization. The association between excitatory response to glucose and the presence of the $\mathrm{K}_{\text {ATP }}$ channel was made explicit by recent studies showing that the same neurons respond to glucose and to sulfonylurea receptor ligands that bind to and stimulate the $\mathrm{K}_{\text {ATP }}$ channel $(39,101,174)$.

On the basis of electrophysiological and cellular analyses it appears that two regions of the brain - hypothalamus and caudal brainstem - contain cells sensitive to glucose level. Oomura and colleagues $(137,138)$ showed that parenchymal application of glucose alters the activity of lateral and ventromedial hypothalamic neurons. These investigators extended their analyses to include caudal brainstem substrates, and showed that NTS neurons also displayed similar responses $(63,124)$ and that the percentage of medullary neurons with 
these response profiles (20-40\%) was similar to that seen in hypothalamus. Dallaporta et al. (38) extended the analysis of NTS neurons, reporting somewhat higher proportions of glucose-sensitive and glucose-responsive neurons, with very little glycemic response in neurons on the other side of the NTS boundary. Studies noted above evaluating electrophysiological response to glucose and sulfonylurea ligands have targeted the arcuate nucleus of the hypothalamus and the caudal nucleus of the NTS $(39,101,174)$. The brainstem has not been probed widely for additional sites, but at least one of relevance is hinted at by a study demonstrating in the ventrolateral medulla (VLM) immunoreactivity for glucokinase, which is associated with the rate of ATP production in the pancreatic beta cell (117). The significance of DVC and VLM is reinforced by functional studies described below.

Electrophysiological evidence for neuronal response to glucose does not by itself imply functional relevance to intake control. To address this issue, researchers have delivered to the brain nonmetabolizable glucose analogues such as 2-deoxy-D-glucose (2DG) and 5-thio-glucose (5TG). These metabolic inhibitors induce cytoglucopenia and provoke compensatory responses, most prominently hyperphagia and sympathoadrenal-mediated hyperglycemia, that would be expected when the brain detects a systemic metabolic depletion or privation. (A neuroendocrine-mediated corticosterone response has been described recently and will be discussed at a later juncture.) The first studies addressing the central bases for these effects involved lateral icv injection, which induced robust feeding and hyperglycemic responses. Until the experiments of R. Ritter and colleagues (146), it was presumed that hypothalamic interoceptors mediated the effects observed. They reported that lateral-icv injection was without effect if the caudal flow of cerebrospinal fluid to the brainstem was blocked by a cerebral aqueduct plug. The icv effect, therefore, can be attributed entirely to stimulation of caudal brainstem interoceptors, an inference supported by positive results obtained with 4th-icv injection $(58,146$; see also 44). S. Ritter and colleagues (149) extensively mapped the caudal brainstem parenchyma with injections of a low dose of 5TG. They reported that positive responses could be triggered from a large number of injection sites that were clustered in the dorsal-medial and ventral-lateral medulla. The positive placements, significantly (see below), are coextensive with catecholamine cell groups (C1-C3; A1-A2). Although a large majority of positive placements in each cluster supported both behavioral and sympathoadrenal responses, some sites drove one or the other. Dissociability of the two responses had been anticipated by Flynn and Grill (58) who showed that 4th-icv 5-TG elicited both responses but that phlorizin, another inhibitor of glucose metabolism, induced hyperphagia without hyperglycemia. These results argue against a singular integrative substrate (whether in forebrain or hindbrain) that receives interoceptive input and distributes commands to the respective effector mechanisms (see also 147, and below).

Given the clear electrophysiological and cell biological evidence for glucosesensing mechanisms in the hypothalamus, it might seem curious that their functional relevance to feeding control could not be supported through admin- 
istration of metabolic inhibitors to the forebrain ventricles. Of course, icv infusion studies are not by themselves definitive because of the unknown but surely limited parenchymal penetration. The issue has been pursued through localized delivery of glucose analogues to hypothalamic substrates. Some indication of a positive response was provided by Borg et al. (18), who focused specifically on the $\mathrm{VMH}$ and reported clear hyperglycemic responses to 2DG (see also 16, 17). This study, however, can be criticized because of its injection volume (several times that used in icv injection studies), raising the possibility that the site of action may have been elsewhere in the hypothalamus or other levels of the neuraxis. Indeed, other groups have tried and failed to report feeding or glycemic responses to microinjection of metabolic inhibitors to hypothalamic structures $(9,122)$. The most extensive study was that of S. Ritter and colleagues (149), in which 5TG was delivered to several hypothalamic structures (including arcuate, lateral, paraventricular, and ventromedial nuclei) to no effect. We must, at present, conclude that the single-site studies do not affirm the potential contribution to energy homeostasis of hypothalamic glucose-sensing neurons. It should be conceded, however, that the single-site approach might not be the most appropriate for probing the effects of systemic signals that under physiological conditions can be detected at several sites within the brain. Studies yet to be performed in which metabolic inhibitors are delivered to two or more sites may reveal amplified responses, suggesting synergistic interaction between hypothalamic and brainstem glucose-sensing mechanisms.

Reductionistic tools, like targeting individual sites with treatments that affect a given class of interoceptors, are indispensable for elucidating the CNS controls of energy balance. At the same time, the pharmacological character of this work must be acknowledged. The metabolic inhibitors, for example, induce a depletion that the brain never sees even when the animal is starved. Similarly for the electrophysiological studies, the change in extracellular glucose concentration used to provoke a neural response falls outside the physiological range (see discussion in 112). Yettefti et al. (205), however, showed that the same cells that respond to iontophoretic application of glucose also respond predictably to increases and decreases in peripheral glycemia to levels that are consistent with the respective physiological profiles of feeding and fasting. Two points may be taken from this observation. First, the result upholds the physiological relevance of the local manipulation studies despite the requirement for supranormal stimulation. Second is the suggestion that the sufficiency of more modest peripheral perturbations to drive these cells reflects synergistic interactions: (i) between interoceptive mechanisms sensitive to plasma glucose and to other blood-borne signals whose levels covary with peripheral glycemia (e.g., insulin, corticosterone, and glucagon) and (ii) between pathways carrying interoceptive information that converge on brainstem and/or hypothalamic integrators. These possibilities set the stage for experiments, yet to be fully exploited, in which more than one interoceptive stimulus is delivered and the integrated effect on behavior is observed. One example appropriate to the present discussion is the hypophagia observed in 
response to leptin and insulin given in combination at doses that were subthreshold for response to either given alone (S. C. Woods and R. J. Seeley, personal communication).

We can note early developments in the very important effort toward characterizing, at the cellular and network levels, the central integration of peripheral signals associated with fluctuations in metabolic status. There is evidence indicating that some degree of multimodal integration can occur at the level of individual neurons. Thus, a population of individual arcuate and VMH neurons express the $K_{\text {ATP }}$ channel and receptors for both leptin and insulin. In these cells, leptin causes a hyperpolarization that depends on the $\mathrm{K}_{\text {ATP }}$ channel, and the hyperpolarizing effect of insulin depends on the presence of Ob-Rb $(174,175)$. Proopiomelanocortin (POMC) neurons within the arcuate represent a different subpopulation of multimodal cells in which depolarization is obtained in response to increases in levels of leptin, insulin, and glucose (37; and M. A. Cowley, personal communication). The fact that individual cells can yield different electrophysiological responses to the same set of signals, along with the indication that there are cells that respond to some but not all of these interoceptive signals (166), makes it clear that an understanding of the integration of these interoceptive signals will require attention to local circuits in critical structures such as the arcuate nucleus. It is also clear that an understanding of the various physiological and behavioral responses to changes in state will require that the same approaches to the arcuate nucleus be applied to cellular mechanisms and network characteristics within other nuclei containing cells receptive to the same set of blood-borne signals. Given evidence reviewed in this section (i.e., CBS interoceptor distributions and functional consequences of localized interoceptor stimulation), it will surely be important to apply such analyses to brainstem nuclei, an effort that has barely begun.

Although the brainstem mechanisms must be addressed on their own terms, characterization of arcuate hypothalamic substrates offers, as a place to begin, hypotheses about cellular phenotypes and network characteristics of brainstem systems. One wonders whether the POMC neurons in the commissural NTS express Ob-Rb, insulin receptors, and the $\mathrm{K}_{\text {ATP }}$ channel as do POMC neurons in the arcuate, and whether stimulation of the respective receptors similarly depolarizes cell membranes. Many more brainstem studies can be driven by relationships worked out for hypothalamic substrates. There are, of course, limits to the extent of the brainstem- hypothalamus parallels that can be drawn. Thus, for example, Ob-Rb is coexpressed with AgRP in arcuate neurons, whereas the caudal brainstem contains no AgRP perikarya. Similarly, research indicates $(38,147,149)$ that glucose interoceptors are coextensive with, or coexpressed within, norepinephrine and epinephrine neurons in the DVC and VLM, whereas cell bodies for these catecholamines are not found in forebrain. Determination of the neurotransmitter phenotypes of the neurons sensitive to blood-borne correlates of metabolic state begins the discussion taken up in the next section, addressing the transmission of interoceptive 
information to other substrates, nearby and distant, involved in energy balance.

\section{NEUROPEPTIDE MEDIATION}

Neurochemical systems have been at the for efront of the analysis of feeding behavior for at least 50 years. This enterprise has been transformed by the discovery of leptin, in that the weight of the effort has shifted to neuropeptide mediators of leptin action including peptides in neurons that coexpress Ob-Rb. These neuropeptides themselves have potent effects on intake and energy balance and include those with anorexic action [e.g., alpha-melanocyte-stimulating hormone (MSH), cocaine- and amphetamine-related transcript (CART), corticotropin-releasing hormone $(\mathrm{CRH})]$ and others that stimulate intake [e.g., neuropeptide Y (NPY), agouti-related peptide (AgRP)]. The pattern of projections of these peptide neurons within the hypothalamus (e.g., arcuate to PVN and arcuate to $\mathrm{LH}$ ) constitutes the circuits central to the contemporary hypothalamic control model (e.g., 21, 46, 49, 84, 153). Within this hypothalamic network we have an array of interoceptors (reviewed above) and the embodiment, according to the model, of the integrative mechanism from which arises command lines to neuroendocrine, behavioral, and autonomic effector mechanisms.

The lack of attention to caudal brainstem is an unfortunate oversight given the effects that arise from brainstem interoceptive stimulation, as reviewed above, the potency of important ascending systems, as reviewed below, and the fact that receptors if not cell bodies for almost all of the peptide systems in focus are distributed widely in the brain, with notable expression in the caudal brainstem. In the following we review the implications of forebrain and brainstem action of a selected set of peptide mediators, with particular attention on the melanocortin and $\mathrm{CRH} /$ urocortin systems.

\section{Melancortin}

Compelling evidence has accumulated rapidly linking melanocortin 3 and 4 receptors (MC3-R and MC4-R) and their ligands to the control of intake and metabolism (e.g., 29, 34, 51, 52, 91, 97, 115, 135, 190). Alpha-MSH (a cleavage product of POMC) is the endogenous agonist and AgRP is an endogenous antagonist, for these receptors. The role of the melanocortin system in energy balance is often discussed in relation to the downstream mediation of leptin's action. Consistent with this perspective: (i) leptin receptors are expressed on arcuate hypothalamic neurons that also express POMC or AgRP, (ii) leptin treatment increases expression of POMC mRNA and decreases AgRP mRNA, and (iii) the synthetic melanocortin 3/4 receptor (MC3/4-R) antagonist, SHU9119, reverses the short-term intake inhibition that follows icv application of leptin $(123,164,201)$. Direct agonist stimulation of MC3/4-R via icv treatment 
produces a short-latency, doserelated inhibition of food intake that lasts for $24 \mathrm{~h}$, while antagonist treatment yields a robust hyperphagia that persists for several days after a single application $(70,83)$.

The site of action for the potent intake effects of central MC-R stimulation has been framed exclusively in hypothalamic terms (e.g., 108, 200). Yet the MC4-R, the melanocortin receptor most frequently associated with the intake actions of the central melanocortin system, has its highest density in the DVC (127), and the NTS is one of the two structures in the brain containing POMC neurons. We undertook to explore the functional rel evance of brainstem MC-R via 4th-icv and brainstem parenchymal injection of MTII, a MC3/4-R agonist (see also 25), and of SHU-9119. Each treatment yiel ded dose-related short- and long-term intake effects that were not distinguishable from those obtained from lateral icv delivery (70). On face value, the finding is consistent with the suggestion that the lateral and 4th-icv injections stimulate different subsets of MC-R that independently can give rise to what is essentially the same re sponse. Support for this proposition was obtained from the demonstration that unilateral DVC application of these ligands, at doses that were ineffective when applied to the ventricle, produced robust short- and long-term effects on feeding and body weight change (199). This finding should be viewed alongside the demonstration of feeding responses obtained with PVN injection $(65,102)$. Such data, of course, do not rule out other MC-R-containing regions from which similar responses can be obtained. In fact, preliminary work in our laboratory shows that ventricle-subthreshold doses of MTII and SHU-9119 were effective when delivered to the PBN (66).

\section{CRH/Urocortin}

The corticotropin-releasing hormone $(\mathrm{CRH})$ system has received increasing attention as part of the neurology of energy balance control (145). Its physiological rel evance is suggested by the systematic variation of $\mathrm{CRH}$ peptide level, and of mRNA expression for $\mathrm{CRH}$ and for $\mathrm{CRH}-\mathrm{R}$, in relation to feeding behavior (120), food deprivation (19, 183), and overfeeding (162). Stimulation of central $\mathrm{CRH}$ receptors consistently yields reduction of intake and body weight, with greater attribution to the $\mathrm{CRH}_{2}-\mathrm{R}$ subtype. Urocortin and urocortin II are endogenous $\mathrm{CRH}-\mathrm{R}$ ligands with greater relative potency and affinity for $\mathrm{CRH}_{2}-\mathrm{R}$ than for $\mathrm{CRH}_{1}-\mathrm{R}(144,177)$. When delivered icv, urocortin (177) and urocortin II (144) produce greater intake suppression and fewer stress-related responses than does CRH. The contemporary model has assigned a role for $\mathrm{CRH}$ in the mediation of leptin effects $(156,188,192)$. Thus, $\mathrm{CRH}_{2 a}-\mathrm{R}$ mRNA, CRH mRNA, and peptide level are increased after icv leptin administration $(132,145,192)$, and treatment with a CRH-R antagonist attenuates the intake suppression that otherwise follows icv leptin administration $(64,188)$. The mediating mechanisms for these actions (with possibilities involving, for example, Ob-Rb on $\mathrm{CRH}$ neurons and projections to PVN from 
arcuate neurons containing POMC, CART, AgRP, and NPY (e.g., 85, 42) are yet to be established.

The effects of $\mathrm{CRH}$ receptor stimulation are generally considered in relation to forebrain sources of the endogenous ligand, which include PVN, LH, and central nucleus of the amygdala. The behavioral effects are not likely to reflect direct activation of the hypothalamo-pituitary-adrenal axis (HPA) since the intake suppression attending lateral icv delivery survives hypophysectomy (126). N ot surprisingly, the brainstem had been neglected despite its widespread distribution of $\mathrm{CRH}-\mathrm{R}$ and the presence of neurons that produce $\mathrm{CRH}$, urocortin, and urocortin II $(12,13,144,180)$. We were encouraged to address brainstem contributions by an earlier study of Brown (26) showing that the sympathoadrenal response to $\mathrm{CRH}$ could be elicited from numerous CNS locations, including brainstem sites. With urocortin administration, we showed dose-related intake suppression, with response functions from the fourth ventricle that were almost indistinguishable from those obtained with lateral icv delivery (74). From both placements, intake suppression was measured at 2 and $4 \mathrm{~h}$, and was also observed 24 and $48 \mathrm{~h}$ after treatment with accompanying reductions in body weight. We showed, further, significant suppression of 24-h intake after unilateral injection, at a ventricle-subthreshold dose, to DVC (74) and to PBN (73). It is clear, then, that intake responses can be obtained from both brainstem and forebrain (e.g., 87, 198).

F rom the neuropeptide systems examined as models, we derive the foll owing two major conclusions: that the brainstem contains trigger zones for behavioral response and that similar responses can be obtained by stimulation of disparate receptor subpopulations distributed across brainstem and forebrain structures. There are, of course, many examples of given peptides that are recruited in local circuits in different parts of the brain that serve unrelated functions. There was no reason, therefore, to have expected that the two peptide systems discussed above would give rise to similar effects when ligands were delivered to different locations. But the data are clear with respect to $\mathrm{CRH}$ and the melanocortin system, and the conclusions are likely to extend to other feeding-relevant neuropeptides. Indeed, there is evidence for such distributed action for two other peptides, CART and NPY, implicated in the mediation of leptin's effects on energy balance (e.g., 11, 22, 94, 191, 195). The multiplicity of sites from which a given treatment may trigger the same response has yet to be assimilated into contemporary models for the control of energy balance. One area of progress will entail the identification of the transmitters produced in the respective postsynaptic neurons, or of other downstream transmitters whose blockade interferes with the observed response. There has been some effort along these lines with respect to effects of hypothalamic treatment (e.g., 82, 105). But the question at hand will not be addressed until hypothalamic studies are balanced by a search for relevant local circuits within brainstem and ultimately for sites that receive convergent inputs from different locations from which the same effects can be triggered by a given treatment. Downstream convergence can be assumed, but we have no basis upon which to speculate about which substrate(s) represents the common 
integrator that gives rise to the response observed. The point of convergence could be on premotor networks themselves or, alternatively, on integrative substrates in hypothalamus, caudal brainstem, or both locations, which in turn distribute commands to relevant effector mechanisms.

The upstream implications of the multiple response trigger zones for these peptides can also be perplexing. F ocal pharmacological stimulation "simulates" the action of endogenous ligands for the stimulated receptors. The problem for each peptide discussed here is that the cell bodies of neurons projecting to a given effective injection site are located in both hypothalamus and brainstem. Taking the melanocortin system as an example, it is not clear whether brainstem administration of exogenous agonists stimulates receptors that are normally driven by POMC neurons in the arcuate or by POMC neurons in the NTS. This problem does not apply with mediators whose cells of origin are situated in one structure or region. For oxytocin, a peptide implicated in ingestive control $(136,194)$, responses obtained with receptor agonists delivered to brainstem or forebrain may be taken to simulate endogenous activation of hypothalamic oxytocinergic neurons. By the same simple logic, ingestive responses obtained from hypothalamic application of glucagon-like peptide $\left(G L P_{1}\right)(118)$, another anorexic peptide implicated in the response to leptin (67), arise from receptors normally stimulated by an ascending path from the NTS, the only known source of GLP $P_{1}$ in the brain (107). Finally, the effects of focal catecholamine and serotonin treatments delivered to hypothalamic sites highlight the functional role of largely (for dopamine), or exclusively, brainstem cell groups (see below). However, the problem of attribution when there are two or more potentially relevant sources of endogenous ligand is a persistent one. One approach would entail selective stimulation of individual structures that receive inputs from only one of the sources in question. Regardless of the outcome of experiments motivated by this approach, unaddressed would be the sites that receive convergent inputs from widely separated sources of the same peptide from which ingestive effects are obtained with focal stimulation. Sites of such convergence include but are not limited to the PVN for NPY (e.g., 151, 154), PBN for CRH (103), and NTS and DVC for melanocortins $(93,141)$.

In the previous sections, we reviewed anatomical and functional evidence for the relevance of brainstem interoceptive elements and peptide receptors. The evidence recommends a detailed analysis of brainstem substrates that is no less intensive than that applied to the hypothalamic circuits. It will be important to then build models of the brainstem circuitry and test hypotheses about downstream mediation. Taking a lead from the hypothalamic work, for example, one can ask whether brainstem application of MC3/4-R or CRH-R antagonists reverses effects that arise from brainstem leptin administration (64, $164,188)$. It is also timely to evaluate changes in peptide and peptide receptor expression as functions of physiological manipulations such as deprivation and overfeeding, asking whether similar effects are obtained in brainstem and hypothalamus (see, e.g., 206). Other approaches are needed to address the larger questions posed in this review, relating to the control of intake distrib- 
uted across different levels of the neuraxis under physiological conditions in the intact animal. Along these lines, experiments reviewed in the next section address functional responses stimulated and mediated by circuits within brainstem or forebrain as well as effects that require neural interactions between levels of the neuraxis.

\section{INDE PENDENT PROCESSING CAPABILITIES OF THE CAUDAL BRAINSTEM}

Much of what was reviewed above might lead one to expect that the caudal brainstem in neural isolation from forebrain influence could support some semblance of normal ingestive control. Represented within its boundaries are virtually all known central interoceptor types, gustatory and visceral cranial nerve inputs, a rich complement of neurochemical mediators and receptors of relevance to energy balance, all parasympathetic efferents, centers of sympathetic output control, and finally, all motor neurons and movement pattern generating mechanisms for the production of ingestive behavior. On the other hand, the absence of powerful organizational and command inputs from the hypothalamic feeding control "center" might lead one to expect that patterns of response mustered by the isolated caudal brainstem would be rudimentary, degraded, or otherwise deranged compared to those expressed by the neurologically intact rat. The weight of evidence, however, very much favors the former view. In the following section we review the competence, as well as notable shortcomings, of integrative mechanisms endemic to the brainstem. We are then obliged to consider implications for the whole-brain control of ingestive behavior. We will ask whether brainstem integrative mechanisms stand at the bottom of a neural control hierarchy subject to hypothalamic command control, and will consider the alternative view that integrative centers in brainstem and forebrain regions should be assigned equal rank within the central axis for the control of energy balance.

We have explored the integrative capacity of the caudal brainstem for feeding control through an analysis of the chronically maintained decerebrate rat. These rats have a complete transection of the neuraxis, performed in two stages, at the meso-diencephalic junction (see Fig. 2). Decerebrate rats do not approach food and must be maintained by gavage feeding. Their ingestive function may be explored, nevertheless, by measurement of the behavioral response to direct oral infusions of sapid stimuli. Two oral infusion-based paradigms have been developed. One, "taste reactivity," involves registration of oral-motor responses to brief infusions (76). The other, "intraoral intake," involves an intraoral infusion that is sustained until the rat ceases to ingest; the amount consumed before the satiety criterion is met is analogous to the meal size result of standard short-term intake tests $(75,100,161)$.

The degree of ingestive competence expressed by the chronic decerebrate rat, as probed via these intraoral infusion paradigms, is remarkable. A detailed discussion of their areas of competence was presented in an earlier review (71). We note them briefly: (i) oropharyngeal organization of ingestive behavior. In 


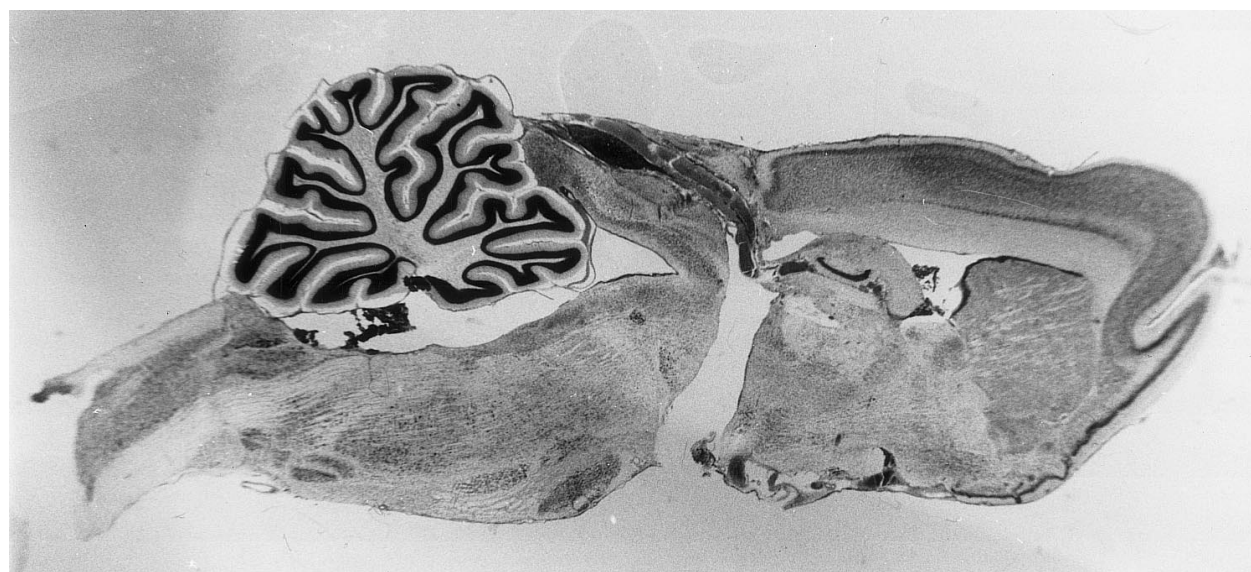

FIG. 2. Representative Nissl-stained sagittal section of a chronically maintained decerebrate rat.

response to intraoral infusion of fluids normally ingested by the rat (e.g., sugar solutions), chronic decerebrate rats display ingestive behavior that is patterned similarly to that observed in neurologically intact controls. Decerebrate and intact rats display the rhythmic, coupled movements of the jaw and tongue, emitted at a frequency $(5-8 \mathrm{~Hz})$ characteristic of the spout-licking behavior of the intact rat. Swallowing is initiated periodically within bursts of this rhythmic oral motor behavior (Fig. 3), but not during the pauses between bursts (95). With increase in oral infusion (= ingestion) rate, there is little change in the frequency of these oral motor responses, but intact (95) and decerebrate (unpublished data) rats show accommodative increases in both swallow frequency and swallow volume. (ii) Taste reactivity. The character of the behavioral response depends critically on the gustatory properties of the infusate. Upon infusion of fluids that are normally avoided or rejected by the

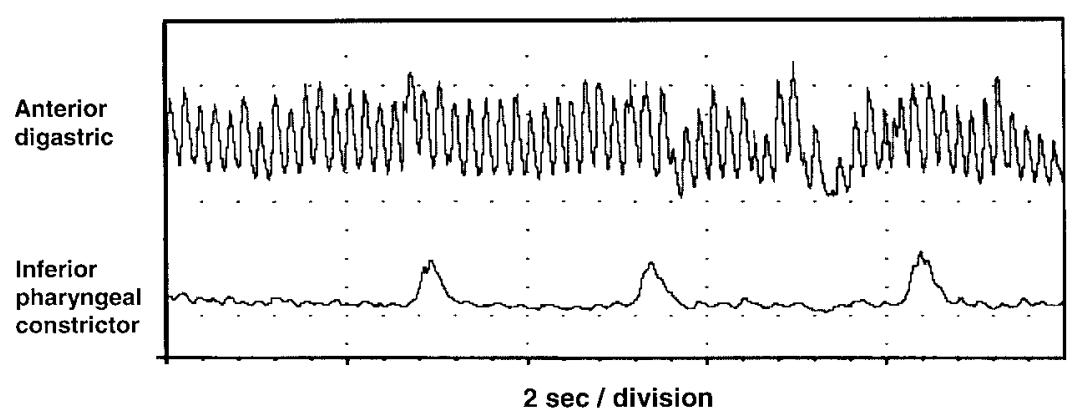

FIG. 3. Electromyographic (full-wave rectified and filtered) recording from the anterior digastric muscle and the inferior pharyngeal constrictor muscle corresponding respectively to rhythmic oral motor and swallowing actions in a decerebrate rat receiving intraorally infused sucrose solution. The pattern is not distinguishable from that obtained from neurologically intact rats. 
intact rat (e.g., quinine solution), the ingestive pattern described above is replaced by an "aversive profile" dominated by gapes and other active rejection responses (76). I mportantly for the present, the decerebrate rat shows the same discriminative responding as a function of taste quality (77). Both decerebrate and intact rats, moreover, display monotonic concentration-oral motor response functions $(59,77,96)$. (iii) Sensitivity to postingestive inhibition. The impact of the accumulating postingestive load on meal size is emphasized in results of the classic sham-feeding paradigm (171). In contrast with normal meals where postingestive inhibition applies, the size and duration of meals are greatly elevated when rats ingest concentrated sugar solutions that drain from an open gastric fistula. We evaluated normal feeding (fistula closed) and sham feeding under the intraoral sucrose intake paradigm and showed indistinguishable responses, in terms of both magnitude and concentration dependency, in intact and decerebrate rats (72). Grill and Smith (80) also showed intact-like sensitivity in decerebrate rats responding to the intake inhibitory effects of peripheral injection of cholecystokinin, one of the likely hormonal contributors to postingestive inhibition (171) whose action is mediated by receptors on vagal afferents (172). Other experiments confirm that meal size in decerebrate rats is under normal postingestive control via visceral afferent signals originating in the gut $(59,81,160)$.

We can conclude that the decerebrate rat shows a fundamentally normal oropharyngeal organization of meal taking and, moreover, is sensitive to the same taste and postingestive feedback signals that codetermine meal size in the neurologically intact rat. These signals, driven by the chemical and mechanical properties of food, are relayed to the caudal brainstem largely via the vagus and other cranial nerves. The view that hypothalamic processing of such visceral afferent information is required for organized and adaptive behavioral response is firmly countered by the integrative achievements of the chronic decerebrate rat.

\section{Neurochemical Mediation}

A set of pharmacological experiments demonstrates similar ingestive responses in chronic decerebrate and intact rats. In addition to the cholecystokinin experiment noted above, evidence for a brainstem site of action is available for bombesin, another gut peptide released by the presence of food (119). A brainstem emphasis is supported by dose-response curves for lateralicv administration that are substantially right-shifted from those obtained when bombesin is delivered to the fourth ventricle (106). Flynn and Robillard (60), moreover, showed intake-inhibitory responses to 4th-icv bombesin in decerebrate rats. Berridge and Pecina (8, see also 89$)$ similarly emphasized brainstem mechanisms in the action of benzodiazepine receptors on ingestive behavior. They showed that 4th-icv cannula placements were more sensitive to benzodiazepine treatment than were lateral icv placements and that intactlike responses were obtained in chronic decerebrate rats. For urocortin, pre- 
liminary results (S. Markison, unpublished data) indicate that 4th-icv delivery suppresses intraoral intake in decerebrate rats as it does in neurologically intact controls. It is not clear, to revisit an issue discussed earlier, whether it is brainstem or forebrain neurons that normally supply endogenous ligand to the $\mathrm{CRH}$ receptors stimulated by exogenous drug delivery. The latter possibility is a strong one even in decerebrate rats because although the descending pathways are severed by transection, it is extremely unlikely that their postsynaptic receptor complements are eliminated. Despite a number of interpretive issues that can be raised, there are two strong conclusions to be drawn-that the stimulated receptors act through a pathway endemic to the brainstem that gives rise to the behavioral effects observed, and that while long-loop mechanisms may contribute to the response of intact rats, forebrain mediation is not necessary for coordinated and predictable ingestive response to these treatments.

Neurochemical analysis of the behavioral response of the decerebrate rat is still in early development. Certain constraints should be noted about the number of relevant treatments that can be explored with this preparation. The limitations relate to the difference between standard intake tests and intraoral intake, the latter being the only means by which to probe intake responses of the decerebrate. In general, intraoral intake is a good model for studying factors underlying normal meal size control. Thus, intraoral intake is sensitive to the prototypical physiological manipulations (e.g., deprivation, preloading) and a variety of taste and postingestive treatments (59, 97, 160). Several pharmacological treatments, however, affect meal size in standard tests but affect intraoral intake either weakly or not at all $(163,202)$. A discussion of the methodological contrasts relating to appetitive and consummatory phases of intake control is beyond the scope of this review. We are left, in any event, with the practical problem of assessing the contribution of some receptor systems that may influence behavior through mechanisms endemic to the brainstem but which cannot be probed for ingestive effect in the decerebrate. The limitation applies to testing intact rats in the same paradigm and ther efore should not be held against the decerebrate (cf. 170). There is more than enough encouragement to explore the large number of treatments that no doubt will yield positive effects and compelling implications in decerebrates.

Central serotonin and dopamine systems have long standing in the field of ingestive behavior analysis (e.g., 35, 173, 181, 182) and can be effectively probed with the intraoral intake paradigm. Peripheral administration of the indirect serotonin agonist, D-fenfluramine, and of the $5-\mathrm{HT}_{2 \mathrm{C} / 1 \mathrm{~B}}$ agonist, $\mathrm{mCPP}$, yields intake-suppressive effects reflecting action at central receptors. Both compounds given to the fourth ventricle yield dose-related suppression of intake in neurologically intact rats $(73,90)$. A necessary role of specifically brainstem receptors in the intact rat's response is demonstrated in a study in which the effect of systemic mCPP delivery was reversed by 4th-icv delivery of a low dose of the $5 \mathrm{HT}_{2 c}$ antagonist, mesulergine (99). Finally, peripheral delivery of $\mathrm{MCPP}$ and $\mathrm{D}$-fenfluramine yielded dose-related suppression of intraoral intake in decerebrate and in pair-fed control rats $(68,99)$. A similar 
profile applies to the actions of dopamine agonists. The decerebrate rat shows an intake suppressive response to systemic apomorphine, a nonspecific dopamine receptor agonist (98). I ntraoral intake is suppressed in the intact rat by quinperole, $a \mathrm{D}_{2}$ agonist, but not by domperidone, an agonist that does not cross the blood- brain barrier. We have collected data in decerebrate rats that show clear intake suppression after systemic quinperole that is reversed by 4th-icv administration of the $D_{2}$ antagonist, raclopride, which itself was without effect when given alone (unpublished observations). Consistent with the conclusions concerning bombesin, benzodiazepine, and $\mathrm{CRH}$, we can conclude that stimulation of these biogenic amine receptors in the brainstem gives rise to behavioral effects via mediating pathways endemic to the caudal brainstem. We had pointed out for the melanocortin and CRH/urocortin system, that it is not yet possible to unambiguously locate the (brainstem or forebrain) sources that supply endogenous ligand to the receptors, that otherwise support the pharmacological effects observed. This interpretive problem does not apply to the dopaminergic and serotonergic effects because all neurons normally innervating the stimulated receptors are contained within the brainstem. Biogenic amine neurons, therefore, represent an element in a pathway, endemic to the caudal brainstem, with potent effects on ingestive behavior. Under physiological conditions, these neurons may receive signals arising from brainstem interoceptors $(33,147,205)$. But because of direct and indirect descending pathways from hypothalamus to these neurons, a possibly critical rolefor basal forebrain interoceptors or integrative mechanisms can never be ruled out. The ambiguities about hypothalamic involvement that complicate the interpretation of pharmacological experiments targeting peptide and amine receptors do not apply to the direct action of blood-borne signals on central interoceptors.

\section{INTEROCEPTOR-DRIVEN RESPONSES}

In an earlier section we noted behavioral and autonomic responses that can be triggered by treatments that stimulate interoceptive mechanisms within the caudal brainstem. The decerebrate preparation can be used to address the potential for brainstem substrates to effect the same responses in isolation of forebrain influence. Decerebrate rats show a fully formed sympathoadrenal response to systemic 2DG administration (44), indicating that the brainstem contains a complete circuit, including interoceptors responsive to the reduction in utilizable glucose and sufficient integrative machinery to engage a descending command to spinal effectors. The ingestive behavioral response to metabolic inhibitors has not been evaluated. However, in response to systemic high-dose insulin, an elevated intraoral intake response is obtained in intact and decerebrate rats (57). It had been concluded that the hyperphagic effect was secondary to the metabolic consequences induced by insulin treatment (179). [Peripheral mediation due to accelerated (62) gastric emptying appears to us an unlikely explanation because an analysis of the emptying of sugar solution showed that the insulin effect was expressed after the period of 

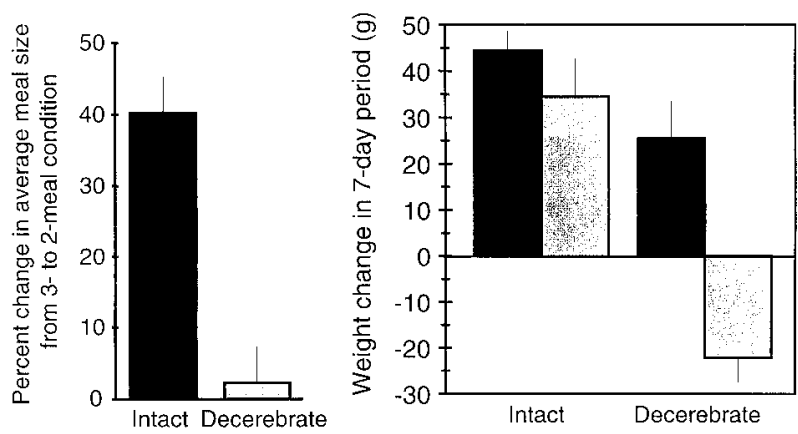

FIG. 4. Results for the "meal omission" experiment during which intact and decerebrate rats ingested either two or three meals per day for a 1-week period. (Left) Percentage change in average meal size when rats were shifted from the three to the two-meals-per-day conditions. (Right) Amount of weight change over the week of testing under the three and two-meals-per-day conditions.

stomach filling (167).] If the effect can be attributed unambiguously to central interoception, then an endemic brainstem circuit can be judged sufficient for expression of an adaptive ingestive response. While not a perfect model, results with high-dose insulin administration might lead one to expect that the decerebrate rat would show a normal-like ingestive response to actual food deprivation. We reviewed evidence earlier indicating that the decerebrate was sensitive to the taste and postingestive feedback signals firmly implicated in the control intake over the short term. In the next section we ask whether the decerebrate is capable of responding to the systemic/metabolic correlates of food deprivation.

\section{FOOD DEPRIVATION IN THE DECEREBRATE RAT}

Our first study in which decerebrate ingestive performance was evaluated over the longer term revealed an apparent deficit. In it, we tested intact and chronic decerebrate rats in the classic meal omission paradigm (111). Rats were tested for 1 week during which three scheduled intraoral intake tests per day were delivered, and for 1 week during which the second meal of each day was omitted. Both decerebrate and intact rats gained weight under the threemeal condition (Fig. 4, right). Intact rats compensated for the lost feeding opportunity under the two-meal condition by increasing the size of each remaining meal (Fig. 4, left). No compensatory response was observed in decerebrate rats that, as a result, lost weight progressively over the course of the week. The experiment thus revealed a disconnection between energy deficit and short-term intake controls.

The indication that the decerebrate may not respond to systemic metabolic correlates of physiological depletion prompted us to revisit an earlier finding (75) that decerebrate rats ingested more when deprived than under control 


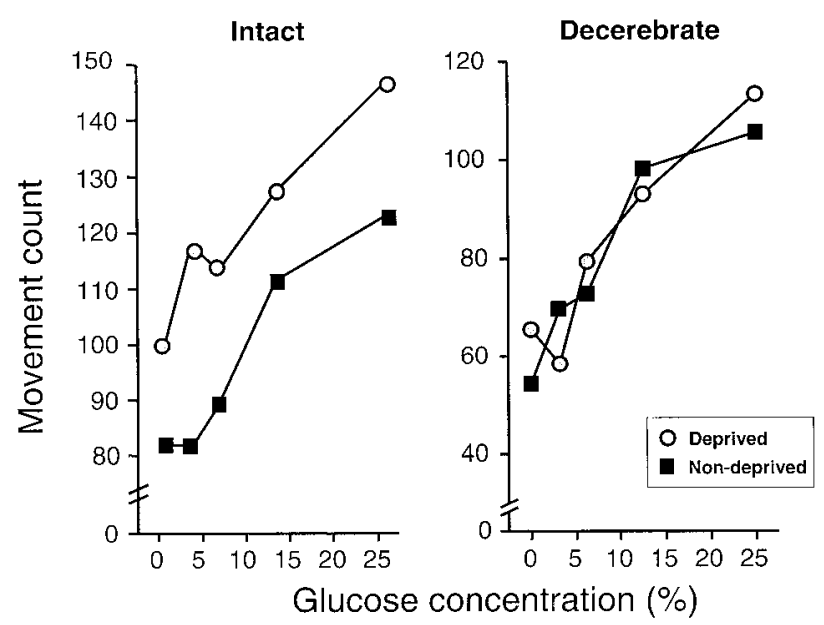

FIG. 5. Effect of deprivation and glucose concentration on the average number of oral movements recorded after 15-s intraoral infusions in intact (left) and chronic decerebrate (right) rats.

conditions. The control condition for that study was one in which the intake test was given after rats had received a gastric prel oad. The differential intake response, then, could have been more related to the suppressive effects of the preload than to the stimulatory effects of deprivation. The problem was that there was no intermediate reference condition against which to evaluate respective excitatory or inhibitory influences. This omission was redressed in an experiment re-representing the deprivation and preload conditions and, adding as an anchor, a condition under which nondeprived rats were tested after the stomach contents had been evacuated. We found that both intact and decerebrate rats ingested more under this reference condition than when preloaded, reaffirming our conclusions about the brainstem's sufficiency for mediating ingestive responses to gastrointestinal fill (160). The intact rats ingested twice as much when deprived as they did under the no-deprivation/ empty-stomach anchor condition. F or the decerebrates, however, there was no difference in intake between these two conditions, indicating, again, a lack of meal-size response to systemic aspects of food deprivation.

A lack of meal size response in the decerebrate does not preclude the possibility that a sensitivity to deprivation would be expressed in the rat's immediate response to taste stimulation. If such sensitivity were demonstrated, then it might be clear that signals related to natural deprivation are received and processed in the brainstem even if this processing is not reflected in the intake outcome of the meal. To explore this possibility, we adopted a paradigm that highlights the additive influence of stimulus concentration and physiological state on the taste reactivity response of the neurologically intact rat (78). The left graph of Fig. 5 shows that the glucose concentration-taste reactivity response functions of 24-h food-deprived intact rats was uniformly elevated relative to nondeprived control values. In contrast, the decerebrate rat (Fig. 5, 
right graph) did not show any separation between the functions obtained under deprivation and nondeprivation conditions. The lack of decerebrate response to deprivation is not due to an impairment in taste reactivity response production as evidenced by their intact-like response to variation in glucose concentration.

\section{TOWARD AN INTERPRETATION OF THE DEFICIENT RESPONSE TO DEPRIVATION IN DECEREBRATE RATS}

In summary, we have explored different paradigms and found no evidence in decerebrate rats of an intact-like behavioral response to deprivation-not in daily intake, in meal size response, or in taste reactivity. These results were not anticipated given an earlier study (57), noted above, showing comparable elevations of intraoral intake in response to high-dose insulin delivery in decerebrate and intact rats. Perhaps an acute depletion, like the pronounced hypoglycemia resulting from high-dose insulin injection, is necessary for a behavioral response in the decerebrate. In any event, it is clear that the judgments derived from this experiment do not offer a perspective from which to think about the effects of natural food deprivation. [See (62) for a critique of insulin as a proxy for natural deprivation.] We must conclude from the results described above that neural interactions between forebrain and brainstem are required for a normal-like feeding response to food deprivation. The nature and significance of the relevant interactions, however, remain open to interpretation.

One might conclude that the caudal brainstem does not possess the integrative machinery for translating interoceptive signals associated with deprivation into an adaptive behavioral (hyperphagic) response. This integrative function, then, would be assigned to forebrain structures. A model along these lines, relying on the full set of decerebrate results described above, was proposed by Smith (170). Smith's formulation hinges on the distinction between what he defines as "direct" and "indirect" controls. The brainstem is seen as responsible for orchestrating responses to direct controls, i.e., signals that arise from direct contact of food with the digestive mucosa. Such signals are generated by oral sensory stimulation and also include vagal and hormonal signals generated by gastric distention and the passage of chyme through the small intestine. Indeed, the sensitivity to these signals defines the unambiguous competence of the decerebrate rat. The indirect controls represent all other influences on ingestive behavior and include blood-borne correlates of deprivation to which brain interoceptors are sensitive. The forebrain is held to contain the substrates that process interoceptive information and modulate, via descending pathways, brainstem response to direct controls. According to our read, the model is not biased about the anatomical origin of the central interoceptors. If the brainstem contains relevant interoceptors, then their behavioral influence would be transmitted via a long-loop arrangement entailing forebrain integrative mediation. 
Recently S. Ritter and colleagues (147) provided evidence consistent with such a long-loop arrangement with respect to the 2DG model. Their findings affirm the dissociability of ingestive and sympathoadrenal responses to 2DG and implicate a particular neurochemical system, namely, the ascending norepinephrine pathway, in the mediation of the hyperphagic response to this metabolic inhibitor. The experimental strategy involved the delivery of antidopamine $\beta$-hydroxylase-saporin (DSAP) bilaterally to the PVN. DSAP causes retrograde degeneration of brainstem catecholamine neurons that project to PVN and, as it turned out, abolishes the feeding response to 2DG. Interestingly, DSAP in the PVN did not affect the sympathoadrenal response to 2DG. The dissociation between feeding and autonomic response to 2DG became a double dissociation when DSAP was applied to the thoracic spinal cord. In this case, a different population of catecholamine neurons was lesioned which disrupted the sympathoadrenal response to 2DG but left the feeding response intact. The latter result is consistent with a study cited above in which the sympathoadrenal response was observed in decerebrates (44). The abolition of the hyperphagic response to 2DG by DSAP into the PVN is consistent with the suggestion that this structure plays an obligate integrative role, and it is tempting to suggest further that the long-loop mechanism is also important for behavioral response to metabolic signals associated with natural deprivation. A cautious position on both counts may be appropriate, however. First, it is known that the same catecholamine cell groups that project to PVN also have terminations within the caudal brainstem (e.g., PBN, see Table 3.5 in Ref. 14 for extensive referencing). Therefore, a contribution, perhaps a necessary one, of brainstem structures also deprived of their norepinephrinergic inputs by DSAP delivery to the PVN cannot be ruled out. It is also appropriate to recall here that while 2DG effects arise from interoceptive events, the model is an imperfect one for natural deprivation. The latter point is brought into clear focus when another result of the same study is considered. Whereas the feeding response to 2DG was disrupted, the hyperphagia attending natural deprivation was not affected by DSAP delivery to the PVN.

While the decerebrate failure to respond to food deprivation may fairly bias us to believe that hypothalamic integration is necessary, it is entirely possible that the brainstem is in fact sufficient for adaptive behavioral responses to natural deprivation in the neurologically intact rat. First, descending projections severed by decerebration may represent, under normal conditions, a permissive factor supporting the ability of brainstem structures to respond to metabolic signals. The normal physiology of important integrative substrates in the brainstem also may be altered by the loss of major ascending projections that pass through the transection plane. Two studies will be noted that speak to the possible relevance of these points to the functional integrity of the brainstem in decerebrate animals. A study by Li et al. (114) revealed that A2 neurons in the DVC survive midpontine hemi-transection, but that Fos immunoreactivity of these neurons under certain stressful conditions was substantially diminished. A perhaps more pertinent example was provided by Horn et al. (90) who evaluated Fos expression in response to systemic 2,5-anhydro-D- 
mannitol (2,5-AM) treatment in intact and decerebrate rats. [2,5-AM is a nonmetabolizable analogue of fructose that stimulates feeding intake via a hepato-vagal mechanism at the dose used in this study (185). Tordoff et al. (184) have argued that 2,5-AM is a better proxy for natural deprivation than 2DG or high-dose insulin with respect to a range of metabolic/endocrine parameters.] In the intact rat, the Fos profile for 2,5-AM includes activation in NTS and PBN and in the forebrain, in PVN and in the central nucleus of the amygdala $(90,148)$. Activation in the PVN and amygdala was eliminated by the transection, indicating that in the normal brain, this activation was transmitted from the brainstem. The NTS activation was not affected by the transection, but most striking was the absence of treatment-related activation in the PBN of the decerebrate rat. It is interesting that the PBN was highlighted in this context (see also, 69, 150). It is true that most attention devoted to the PBN relates to its role as a relay in the ascending transmission of visceral sensory information (133). It is also noteworthy that the PBN is an integrative structure with outputs to other brainstem substrates (e.g., NTS, nucleus ambiguus, ventral lateral medulla, lateral parvocellular reticular formation) (152). This establishes the PBN as a potentially important element in an integrative network endemic to the caudal brainstem that may normally mediate behavioral response to metabolic treatments. Disrupted function of the PBN, NTS, or other brainstem structures, therefore, may contribute to the decerebrate rat's failure to express a hyperphagic response to deprivation. This is a legitimate hypothesis that cannot be evaluated until more information about the extent and operating characteristics of the brainstem neural networks that process deprivation-related signals becomes available.

There are two remaining alternative explanations for the behavioral deficit of the decerebrate rat. One holds that the integrative network that mediates behavioral response to deprivation is distributed across both brainstem and hypothalamic substrates and that the system fails when the integrity of the network as a whole is assaulted. The distributed control model is antithetical to the hypothalamic-single-integrator model, which would otherwise explain the deficit as being due to the elimination of the command lines descending to the brainstem ingestion controller. The prospects for testing this latter explanation, however, are weak at best. A decerebration approach to hypothalamic mediation of behavioral response to deprivation is not applicable because there can be no behavioral read-out from the isolated hypothalamus. It may be instructive, however, to turn the tables and ask whether the forebrain is sufficient for processing deprivation-related signals with respect to its own unique effector system-the neuroendocrine output of the pituitary.

\section{INDEPENDENT PROCESSING CAPABILITIES OF THE HYPOTHALAMUS}

The undisputed contribution of the hypothalamus to energy balance is through its premotor command of pituitary-neuroendocrine effectors. Conditions of food deprivation evoke an adaptive neuroendocrine response that 
includes increased activity of the adrenal axis and the suppression of the thyroid, gonadal, and growth axes (e.g., 4, 24, 131, 155, 197). J ust as we had asked whether the brainstem in isolation of forebrain could muster a behavioral response to deprivation, it is also appropriate to consider whether these neuroendocrine responses to natural deprivation would be disrupted or degraded if the hypothalamus operated without benefit of ascending inputs from the caudal brainstem. The decerebrate rat preparation offers a potentially useful and as yet unexploited approach to this issue. The neuroendocrine profile of the fasted decerebrate may parallel that of the intact rat, indicating, thereby, functional systems from interoceptor to effector that are endemic to the hypothalamus. Work with the glucoprivic and other models, however, suggests an obligate contribution of brainstem interoceptors to adaptive neuroendocrine response.

As with food deprivation, 2DG stimulates the HPA and suppresses the gonadal axis. Evidence suggests that the neuroendocrine response to systemic 2DG (like the behavioral and sympathoadrenal response; see above) arises from stimulation of interoceptors in the caudal brainstem. Pulsatile luteinizing hormone secretion is suppressed by 4th-icv application of 2DG (128), with the ascending NE projection to the PVN implicated in the mediation of this effect (130). F or the HPA-driven corticosterone response to 2DG, Foster and colleagues have shown a stronger response to fourth than to the lateral ventricle application (134). Their interpretation holds a primary site of action in the caudal brainstem, with the lateral-icv effect of 2DG carried with the caudal flow of CSF to the relevant brainstem interoceptors. The ascending pathways mediating this response have not been explicitly pursued, but suggestions may be derived from other paradigms emphasizing brainstem-HPA linkages. The HPA response to a number of stressors (e.g., hemorrhage, hypotension, cytokines) depends on ascending catecholaminergic, particularly noradrenergic, projections arising from the NTS and ventrolateral medulla (e.g., $88,114,139,140)$. Such a NE link for the HPA activation stimulated by 4th-icv 2DG, if one can be demonstrated, would be interesting given that noradrenergic mediation is also implicated in the sympathoadrenal and behavioral effects of 2DG, al beit via different pathways (see above). The particulars of the mediating pathways for the neuroendocrine response are not as important to the present argument as that the relevant pathway(s) are ascending and that the information transmitted is generated by interoceptors in the caudal brainstem. At the same time, however, a possible contribution of hypothalamic interoceptors cannot be ruled out until a number of questions have been addressed: whether hypothalamic glucose interoceptors play a permissive role in the brainstem's generation of the neuroendocrine response; whether forebrain interoceptors can drive a neuroendocrine response in the absence of brainstem inputs (e.g., in a decerebrate preparation); and whether a positive response can be obtained with discrete stimulation of the hypothalamic parenchyma.

Another approach to the interoceptive basis for the neuroendocrine response to deprivation highlights the role of leptin. Reduction in leptin level has been implicated as a critical contributor to all neuroendocrine changes associated 
with fasting. Thus, the neuroendocrine effects of fasting are reversed by systemic administration of leptin that restores plasma leptin to prefasting levels $(2,3,55,129,196)$. The assumption is that it is the hypothalamus that contains the $\mathrm{Ob}-\mathrm{Rb}$ that triggers both the effects of deprivation (by reduced stimulation) and their reversal with exogenous leptin treatment. The assumption appears sensible given identified circuits that link Ob-Rb in the hypothalamus and activity of PVN neurons. For example, Ob-Rb-bearing POMC neurons in the arcuate nucleus that project to TRH-containing cells of the PVN have been implicated in leptin's effect on thyroid secretion $(3,55,109)$. The possibility that leptin receptors in the caudal brainstem contribute to the modulation of endocrine output by fasting was addressed recently by Zhou and Schneider (210), who showed that fasting-induced anestrus was prevented by leptin delivery to the fourth ventricle. This finding adds weight to the prospect that other neuroendocrine responses to fasting are also modulated by brainstem Ob-Rb. Whether the hypothalamus independent of brainstem influence is sufficient for this response or other adaptive neuroendocrine responses to leptin is an empirical question that could be explored in the decerebrate rat. Perhaps the best question that can be asked would concern the relative contribution of anatomically disparate interoceptors under physiological conditions where blood-borne signals are available to both brainstem and forebrain substrates. This question cannot be adequately addressed by reductionistic approaches, such as decerebration and focal stimulation of one region or a single substrate. A better approach to the integration of multisite influences might entail concurrent stimulation of different interoceptor substrates from which summative, synergistic, or other interactive effects might be revealed.

\section{THE CENTRAL INTAKE CONTROL AXIS}

At the highest level, the central system controlling energy balance must coordinate behavioral, autonomic, and endocrine activities appropriate to the metabolic status of the animal. As such, the control system is anatomically distributed across hypothalamus, brainstem, and spinal cord, from which the respective outputs emerge and within which premotor control networks reside. According to the long-standing model, the coordination between these output systems is the responsibility of integrative networks within the hypothalamus. Clearly, the single-integrator model has greatly eroded in recent decades. To be sure, there are powerful descending influences on autonomic (e.g., 28, 168, $208)$ and behavioral $(66,116)$ function. The powerful ascending systems, however, challenge the straightforward relevance of the concept of anatomical hierarchy in the control of energy balance. Ascending pathways support what has been called generalized arousal, but also provide information specifically related to metabolic status that can modulate the activity of hypothalamic neuroendocrine effectors. It seems no less appropriate to speak of the brainstem near the top of a hierarchy controlling neuroendocrine function as it does to name the hypothalamus as the master controller of ingestive behavior. Such 
arguments (regarding hypothalamic versus brainstem primacy) give way to more productive discussion, we think, when the problem of anatomical localization is framed from a systems analysis perspective. In this light we have attempted to recast the discussion in terms of: (i) defined treatments or conditions (e.g., gastric loading, glucoprivation, natural deprivation, leptin treatment) and their effects on respective hypothalamic and brainstem effector systems; (ii) the presence of relevant sensory, particularly interoceptive, inputs at each anatomical level; (iii) whether adaptive responses that arise from these sensory events can be supported by local (i.e., within-level) integrative substrates; and (iv) the extent to which the output function is influenced by input derived from other levels of the control axis.

The strong form of the hypothalamic single-integrator model for ingestive control is definitively rejected by results reviewed above showing that the decerebrate rat displays integrated oral motor and meal-size responses to visceral afferent inputs that are hard to distinguish from those observed in neurologically intact controls. Descending influences in the intact rat, then, may best be seen as modulating activity in sensory-motor networks endemic to the caudal brainstem rather than as direct command lines to behavioral response. The potential relevance of hypothalamic sources of ingestion control is brought back into focus by other decerebrate results, this time pointing to a deficit in their performance with respect to the hyperphagic response to food deprivation observed in intact controls. The deficit then may reflect the lost output of a critical complement of hypothalamic interoceptors sensitive to the systemic/metabolic correlates of deprivation and/or a response in the intact rat that requires hypothalamic integration of deprivation-related signals. This perspective resonates with what could be called the contemporary hypothalamic model of intake control, with signals related to metabolic status and long-term intake control processed in the hypothalamus and exerting their behavioral influence via brainstem systems that organize responses as a function of visceral afferent signals (taste and postingestive feedback) governing intake over the short term (e.g., 158, 170, 204). However, it would appear premature to place the hypothalamus on top of a hierarchy for interoceptive control of ingestive behavior if the assignment is based solely on the performance deficit of the decerebrate. The following qualifications were reviewed above: (i) The brainstem contains interoceptors sensitive to metabolic/systemic variables, local stimulation of which gives rise to demonstrable behavioral response. (ii) The behavioral deficit in the decerebrate rat may reflect loss of brainstem function associated with the transection. (iii) It is possible that in the intact rat the hyperphagic response to deprivation requires processing of interoceptive information in the brainstem (i.e., hypothalamic interoceptors and processing are not al one sufficient to drive the behavioral response). There is an alternate view of the neuroanatomical system for the short- and longterm control of energy balance that is not inconsistent with the results reviewed. This, distributionist, perspective holds that local (brainstem; hypothalamus) interoceptive input represents the primary drive of local effector systems (behavioral/vagal; neuroendocrine, respectively). By drawing upon an 
anatomically disparate set of interoceptors the distributionist perspective se cures an accurate representation of the internal environment. According to the view, the coordination of neuroendocrine, autonomic, and behavioral effects emerges from bidirectional projections reporting critical integrations performed within different levels of the neuraxis.

What continues to transfix the field, including us, is the increasingly re solved appreciation of the hypothalamic circuits of clear relevance to energy homeostasis (e.g., 23, 36, 46, 47, 84). However, we think it important to recognize that this circuitry, in its clearest representation, is a neuroendocrine control mechanism linking interoceptive events (especially Ob-Rb stimulation) in the arcuate nucleus to the functional activity of the hypothalamo-pituitary axes (e.g., 2, 3, 56, 129, 131, 196). In contrast to the clarity of this structurefunction relationship, the manner by which the hypothalamic circuit's defined and no doubt important descending pathways modulate behavioral output is quite vague. In fact, it is not yet possible to define the brainstem circuits through which visceral afferent signals exert their demonstrable and potent effects on the brainstem's own output system-the ongoing ingestive behavior of the animal. Unlike the pituitary control system, the mechanism that controls ingestive behavior is not localizable to an anatomically discrete substrate. First, the relevant motor neuron pools are situated in pontine, medullary, and spinal levels $(43,53,187)$. More importantly, ingestive behavior is modulated less in relation to intensity of movement than to the engagement and disengagement of a pattern generator mechanism that establishes the rhythmic character of consummatory behavior and entrains, accordingly, the activity of jaw, tongue, and pharyngeal musculature. This pattern generator mechanism is itself distributed across a broad swath of brainstem tegmentum $(32,187)$. Although there is a neurophysiological literature that characterizes endoge nous brainstem, and descending, influences on elements of this premotor control system, we know little about where, and nothing about how, visceral afferent or interoceptor influences are translated into the dimensions [e.g, ingestion rate, burst/pause patterning within meals; see for example, (41) and (176)] along which ingestive behavior is modulated under physiological conditions. On the sensory side, brainstem circuits should be approached with the same intensity as has driven the specification of the hypothalamic mechanisms. The brainstem mechanism should similarly yield to analysis of the location and cellular biology of interoceptors and of the neurochemical phenotypes of the substrates that mediate their direct influence on ingestive behavior and on the anterior portions of the central axis for the control of energy balance.

\section{REFERENCES}

1. Ahima RS, Flier J S. Leptin. Annu Rev Physiol 2000; 62: 413- 437.

2. Ahima RS, Kelly J, Elmquist J K, Flier J S. Distinct physiologic and neuronal responses to decreased leptin and mild hyperleptinemia [See comments]. Endocrinology 1999; 140: 4923- 4931. 
3. Ahima RS, Prabakaran D, Mantzoros C, Qu D, Lowell B, Maratos-Flier E, Flier J S. Role of leptin in the neuroendocrine response to fasting. Nature 1996; 382: 250-252.

4. Ahima RS, Saper CB, Flier J S, Elmquist J K. Leptin regulation of neuroendocrine systems. Front Neuroendocrinol 2000; 21: 263-307.

5. Baskin DG, Figlewicz LD, Seel ey RJ , Woods SC, Porte D, Schwartz MW. Insulin and leptin: Dual adiposity signals to the brain for the regulation of food intake and body weight. Brain Res 1999; 848: 114-123.

6. Baskin DG, Schwartz MW, Seeley RJ, Woods SC, Porte D, J r, Breininger J F, J onak Z, Schaefer J , Krouse M, Burghardt C, Campfield LA, Burn P, Kochan J P. Leptin receptor long-form splice-variant protein expression in neuron cell bodies of the brain and colocalization with neuropeptideY mRNA in the arcuate nucleus. J Histochem Cytochem 1999; 47: 353-362.

7. Bernardis LL, Bellinger LL. The dorsomedial hypothalamic nucleus revisited: 1998 update. Proc Soc Exp Biol Med 1998; 218: 284-306.

8. Berridge KC, Pecina S. Benzodiazepines, appetite, and taste palatability. Neurosci Biobehav Rev 1995; 19: 121-131.

9. Berthoud HR, Mogenson GJ . Ingestive behavior after intracerebral and intracerebroventricular infusions of glucose and 2-deoxy-D-glucose. Am J Physiol 1977; 233: R127-R133.

10. Berthoud HR, Powley TL. Characteristics of gastric and pancreatic responses to vagal stimulation with varied frequencies: Evidence for different fiber calibers? J Auton Nerv Syst 1987; 19: 77- 84.

11. Billington CJ, Briggs J E, Harker S, Grace M, Levine AS. Neuropeptide Y in hypothalamic paraventricular nucleus: A center coordinating energy metabolism. Am J Physiol 1994; 266: R1765-R1770.

12. Bittencourt J, Sawchenko PE. Do centrally administered neuropeptides access cognate receptors?: An analysis in the central corticotropin-releasing factor system. J Neurosci 2000; 20: 1142-1156.

13. Bittencourt J C, Vaughan J, Arias C, Rissman RA, Vale WW, Sawchenko PE. Urocortin expression in rat brain: Evidence against a pervasive relationship of urocortin-containing projections with targets bearing type 2 CRF receptors. J Comp Neurol 1999; 415: 285-312.

14. Blessing WW. The Lower Brainstem and Bodily Homeostasis. New York: Oxford Univ. Press, 1997.

15. Booth DA. Food intake and chemical senses. In: Katuski $Y$, Sato M, Takagi SF, Oomura Y, Eds. Metabolic Expectancies. Tokyo: Univ. of Tokyo Press, 1977: 317-330.

16. Borg MA, Sherwin RS, Borg WP, Tamborlane WV, Shulman GI. Local ventromedial hypothalamus glucose perfusion blocks counterregulation during systemic hypoglycemia in awake rats. J Clin Invest 1997; 99: 361-365.

17. Borg WP, During MJ, Sherwin RS, Borg MA, Brines ML, Shulman GI. Ventromedial hypothalamic lesions in rats suppress counterregulatory responses to hypoglycemia. J Clin Invest 1994; 93: 1677-1682.

18. Borg WP, Sherwin RS, During MJ , Borg MA, Shulman GI. Local ventromedial hypothalamus glucopenia triggers counterregulatory hormone release. Diabetes 1995; 44: 180-184.

19. Brady LS, Smith MA, Gold PW, Herkenham M. Altered expression of hypothalamic neuropeptide mRNAs in food-restricted and food-deprived rats. Neuroendocrinology 1990; 52: 441- 447.

20. Breininger JF, Baskin DG. Fluorescence in situ hybridization of scarce leptin receptor mRNA using the enzyme-labeled fluorescent substrate method and tyramide signal amplification. J Histochem Cytochem 2000; 48: 1593-1600.

21. Broberger $C$. Hypothalamic cocaine- and amphetamine-regulated transcript (CART) neurons: Histochemical relationship to thyrotropin-releasing hormone, melanin-concentrating hormone, orexin/hypocretin and neuropeptide Y. Brain Res 1999; 848: 101-113. 
22. Broberger C. Cocaine and amphetamine-related transcript (CART) and food intake: Behavior in search of anatomy. Drug Dev Res 2000; 51: 124-142.

23. Broberger C, De Lecea L, Sutcliffe J G, Hokfelt T. Hypocretin/orexin- and melanin-concentrating hormone-expressing cells form distinct populations in the rodent lateral hypothalamus: Relationship to the neuropeptide $Y$ and agouti gene-related protein systems. J Comp Neurol 1998; 402: 460-474.

24. Brogan RS, Fife SK, Conley LK, Giustina A, Wehrenberg WB. Effects of food deprivation on the GH axis: Immunocytochemical and molecular analysis. Neuroendocrinology 1997; 65: 129-135.

25. Brown KS, Gentry RM, Rowland NE. Central injection in rats of alpha-melanocytestimulating hormone analog: Effects on food intake and brain Fos. Regul Pept 1998; 78: 89-94.

26. Brown MR. Corticotropin releasing factor: Central nervous system sites of action. Brain Res 1986; 399: 10-14.

27. Bruning J C, Gautam D, Burks DJ , Gillette J, Schubert M, Orban PC, Klein R, Krone W. Muller-Wieland D, Kahn CR. Role of brain insulin receptor in control of body weight and reproduction. Science 2000; 289: 2122-2125.

28. Buijs RM, Van der Beek EM, Renaud LP, Day TA, J hamandas J H. Oxytocin localization and function in the A1 noradrenergic cell group: Ultrastructural and electrophysiological studies. Neuroscience 1990; 39: 717-725.

29. Butler AA, Kesterson RA, Khong K, Cullen MJ, Pelleymounter MA, Dekoning J, Baetscher $\mathrm{M}$, Cone RD. A unique metabolic syndrome causes obesity in the melanocortin-3 receptordeficient mouse. Endocrinology 2000; 141: 3518-3521.

30. Campbell CS, Davis J D. Licking rate of rats is reduced by intraduodenal and intraportal glucose infusion. Physiol Behav 1974; 12: 357-364.

31. Campfield LA, Smith FJ , Burn P. The OB protein (leptin) pathway-A link between adipose tissue mass and central neural networks. Hormone Metab Res 1996; 28: 619-632.

32. Chandler $\mathrm{SH}, \mathrm{Tal} \mathrm{M}$. The effects of brain stem transections on the neuronal networks responsible for rhythmical jaw muscle activity in the guinea pig. J Neurosci 1986; 6: 1831-1842.

33. Collin M, Hakansson-Ovesjo M, Misane I, Ogren SO, Meister B. Decreased 5-HT transporter mRNA in neurons of the dorsal raphe nucleus and behavioral depression in the obese leptin-deficient ob/ob mouse. Brain Res Mol Brain Res 2000; 81: 51-61.

34. Cone RD. The central melanocortin system and energy homeostasis. Trends Endocrinol Metab 1999; 10: 211-216.

35. Cooper SJ . 5-HT and ingestive behavior. In: Marsden CA, Heal DJ , Eds. Central Serotonin Receptors and Psychotropic Drugs. London: Blackwell Scientific, 1992: 260-291.

36. Cowley MA, Pronchuk N, Fan W, Dinulescu DM, Colmers WF, Cone RD. Integration of NPY, $A G R P$, and melanocortin signals in the hypothalamic paraventricular nucleus: Evidence of a cellular basis for the adipostat. Neuron 1999; 24: 155-163.

37. Cowley MA, Smart J L, Rubinstein M, Cerdan MG, Diano S, Horvath TL, Cone RD, Low MJ . Leptin activates anorexigenic POMC neurons through a neural network in the arcuate nucleus. Nature 2001; 411: 480- 484.

38. Dallaporta M, Himmi T, Perrin J , Orsini J C. Solitary tract nucleus sensitivity to moderate changes in glucose level. NeuroReport 1999; 10: 2657-2660.

39. Dallaporta M, Perrin J, Orsini J C. Involvement of adenosine triphosphate-sensitive $\mathrm{K}^{+}$channels in glucose-sensing in the rat solitary tract nucleus. Neurosci Lett 2000; 278: 77- 80.

40. Davis J D, Campbell CS. Peripheral control of meal size in the rat: Effect of sham feeding on meal size and drinking rate. J Comp Physiol Psychol 1973; 83: 379-387. 
41. Davis J D, Levine MW. A model for the control of ingestion. Psychol Rev 1977; 84: 379- 412

42. Diano S, Naftolin F, Goglia F, Horvath TL. Segregation of the intra- and extrahypothalamic neuropeptide $Y$ and catecholaminergic inputs on paraventricular neurons, including those producing thyrotropin-releasing hormone. Regul Pept 1998; 7576: 117-126.

43. DiNardo LA, Travers J B. Distribution of fos-like immunoreactivity in the medullary reticular formation of the rat after gustatory elicited ingestion and rejection behaviors. J Neurosci 1997; 17: 3826-3839.

44. DiRocco RJ, Grill HJ. The forebrain is not essential for sympathoadrenal hyperglycemic response to glucoprivation. Science 1979; 204: 1112-1114.

45. Elias CF, Aschkenasi C, Lee C, Kelly J , Ahima RS, Bjorback C, Flier J S, Saper CB, Elmquist J K. Leptin differentially regulates NPY and POMC neurons projecting to the lateral hypothalamic area. Neuron 1999; 23: 775-786.

46. Elias CF, Kelly J F, Lee CE, Ahima RS, Drucker DJ, Saper CB, Elmquist J K. Chemical characterization of leptin-activated neurons in the rat brain. J Comp Neurol 2000; 423: 261-281.

47. Elias CF, Saper CB, Maratos-Flier E, Tritos NA, Lee C, Kelly J, Tatro J B, Hoffman GE, Ollmann MM, Barsh GS, Sakurai T, Yanagisawa M, Elmquist J K. Chemically defined projections linking the mediobasal hypothalamus and the lateral hypothalamic area. J Comp Neurol 1998; 402: 442-459.

48. Elmquist J K, Bjorbaek C, Ahima RS, Flier J S, Saper CB. Distributions of leptin receptor mRNA isoforms in the rat brain. J Comp Neurol 1998; 395: 535-547.

49. Elmquist J K, Elias CF, Saper CB. From lesions to leptin: Hypothalamic control of food intake and body weight. Neuron 1999; 22: 221-232.

50. Elmquist J K, Maratos-Flier E, Saper CB, Flier J S. Unraveling the central nervous system pathways underlying responses to leptin. Nat Neurosci 1998; 1: 445- 450.

51. Fan W, Boston BA, Kesterson RA, Hruby VJ , Cone RD. Role of melanocortinergic neurons in feeding and the agouti obesity syndrome [See comments]. Nature 1997; 385: 165-168.

52. Faroogi IS, Yeo GS, Keogh J M, Aminian S, J ebb SA, Butler G, Cheetham T, O'Rahilly S. Dominant and recessive inheritance of morbid obesity associated with melanocortin 4 receptor deficiency [See comments]. J Clin Invest 2000; 106: 271-279.

53. Fay RA, Norgren R. Identification of rat brainstem multisynaptic connections to the oral motor nuclei using pseudorabies virus. I. Masticatory muscle motor systems. Brain Res Brain Res Rev 1997; 25: 255-275.

54. Fei H, Okano HJ , Li C, Lee GH, Zhao C, Darnell R, Friedman J M. Anatomic localization of alternatively spliced leptin receptors (Ob-R) in mouse brain and other tissues. Proc Natl Acad Sci USA 1997; 94: 7001-7005.

55. Fekete C, Legradi G, Mihaly E, Huang QH, Tatro J B, Rand WM, Emerson CH, Lechan RM. $\alpha$-Melanocyte-stimulating hormone is contained in nerve terminals innervating thyrotropin-releasing hormone-synthesizing neurons in the hypothalamic paraventricular nucleus and prevents fasting-induced suppression of prothyrotropin-releasing hormone gene expression. J Neurosci 2000; 20: 1550-1558.

56. Finn PD, Cunningham MJ , Pau KY, Spies HG, Clifton DK, Steiner RA. The stimulatory effect of leptin on the neuroendocrine reproductive axis of the monkey. Endocrinology 1998; 139: 4652- 4662.

57. Flynn FW, Grill HJ . Insulin elicits ingestion in decerebrate rats. Science 1983; 221: 188190.

58. Flynn FW, Grill HJ . Fourth ventricular phlorizin dissociates feeding from sympathoadrenal hyperglycemia in rats. Brain Res 1985; 341: 331-336.

59. Flynn FW, Grill HJ . I ntraoral intake and taste reactivity responses elicited by sucrose and sodium chloride in chronic decerebrate rats. Behav Neurosci 1988; 102: 934-941. 
60. Flynn FW, Robillard L. Inhibition of ingestive behavior following fourth ventricle bombesin injection in chronic decerebrate rats. Behav Neurosci 1992; 106: 1011-1014.

61. Folli F, Bonfanti L, Renard E, Kahn CR, Merighi A. Insulin receptor substrate-1 (IRS-1) distribution in the rat central nervous system. J Neurosci 1994; 14: 6412- 6422.

62. Friedman MI, Ramirez I, Wade GN, Siegel LI, Granneman J . Metabolic and physiologic effects of a hunger-inducing injection of insulin. Physiol Behav 1982; 29: 515-518.

63. Funahashi M, Adachi A. Glucose-responsive neurons exist within the area postrema of the rat: In vitro study on the isolated slice preparation. Brain Res Bull 1993; 32: 531-535.

64. Gardner J D, Rothwell NJ , Luheshi GN. Leptin affects food intake via CRF-receptor-mediated pathways. Nat Neurosci 1998; 1: 103.

65. Giraudo SQ, Billington CJ , Levine AS. Feeding effects of hypothalamic injection of melanocortin 4 receptor ligands. Brain Res 1998; 809: 302-306.

66. Glickman SE, Schiff BB. A biological theory of reinforcement. Psychol Rev 1967; 74: 81-109.

67. Goldstone AP, Mercer J G, Gunn I, Moar KM, Edwards CM, Rossi M, Howard J K, Rasheed S, Turton MD, Small C, Heath M M, O'Shea D, Steere J , Meeran K, Ghatei MA, Hoggard N, Bloom SR. Leptin interacts with glucagon-like peptide-1 neurons to reduce food intake and body weight in rodents. FEBS Lett 1997; 415: 134-138.

68. Grill HJ, Donahey J CK, King L, Kaplan J M. Contribution of caudal brainstem to Dfenfluramine anorexia. Psychopharmacology 1997; 130: 375-381.

69. Grill HJ , Friedman MI, Norgren R, Scalera G, Seeley RJ . Parabrachial nucleus lesions impair feeding response elicited by 2,5-anhydro-D-mannitol. AmJ Physiol 1995; 268: R676R682.

70. Grill HJ, Ginsberg AB, Seeley RJ, Kaplan J M. Brainstem application of melanocortin receptor ligands produces long-lasting effects on feeding and body weight. J Neurosci 1998; 18: 10128-10135.

71. Grill HJ , Kaplan J M. Caudal brainstem participates in the distributed neural control of feeding. In: Stricker EM, Ed. Handbook of Behavioral Neurobiology, Vol. 10. New York: Plenum, Press, 1990: 125-149.

72. Grill HJ , Kaplan J M. Sham feeding in intact and chronic decerebrate rats. Am J Physiol 1992; 262: R1070- R1074.

73. Grill HJ , Kaplan J M. Effects of urocortin leptin, and melanocortin receptor ligands delivered to the parabrachial nucleus. Appetite, in press.

74. Grill HJ , Markison S, Ginsberg A, Kaplan J M. Long-term effects on feeding and body weight after stimulation of forebrain or hindbrain CRH receptors with urocortin. Brain Res 2000; 867: 19-28.

75. Grill HJ , Norgren R. Chronically decerebrate rats demonstrate satiation but not baitshyness. Science 1978; 201: 267-269.

76. Grill HJ, Norgren R. The taste reactivity test. I. Mimetic responses to gustatory stimuli in neurologically normal rats. Brain Res 1978; 143: 263-279.

77. Grill HJ , Norgren R. The taste reactivity test. II. Mimetic responses to gustatory stimuli in chronic thalamic and chronic decerebrate rats. Brain Res 1978; 143: 281-297.

78. Grill HJ , Roitman MF, Kaplan J M. A new taste reactivity analysis of the integration of taste and physiological state information. Am J Physiol 1996; 271: R677-R687.

79. Grill HJ , Schwartz MW, Kaplan J M, Foxhall J S, Breininger J F, Baskin DG. Evidence for the caudal brainstem as a target for the inhibitory effect of leptin on food intake. Endocrinology 2002; 143(1): 239-246.

80. Grill HJ , Smith GP. Cholecystokinin decreases sucrose intake in chronic decerebrate rats. Am J Physiol 1988; 254: R853-R856. 
81. Grill HJ, Spector AC, Schwartz GJ, Kaplan J M, Flynn FW. Evaluating taste effects on ingestive behavior. In: Toates FM, Rowland NE, Eds. Feeding and Drinking. New York: Elsevier, 1987: 151-188.

82. Hagan MM, Rushing PA, Benoit SC, Woods SC, Seel ey RJ . Opioid receptor involvement in the effect of AgRP-(83-132) on food intake and food selection. Am J Physiol Regul Integr Comp Physiol 2001; 280: R814-R821.

83. Hagan MM, Rushing PA, Pritchard LM, Schwartz MW, Strack AM, Van der Ploeg LH, Woods SC, Seeley RJ . Long-term orexigenic effects of AgRP-(83-132) involve mechanisms other than melanocortin receptor blockade. Am J Physiol Regul Integr Comp Physiol 2000; 279: R47-R52.

84. Hahn TM, Breininger J F, Baskin DG, Schwartz MW. Coexpression of Agrp and NPY in fasting-activated hypothalamic neurons. Nat Neurosci 1998; 1: 271-272.

85. Hakansson ML, Brown H, Ghilardi N, Skoda RC, Meister B. Leptin receptor immunoreactivity in chemically defined target neurons of the hypothalamus. J Neurosci 1998; 18: 559-572.

86. Halaas J L, Gajiwala KS, Maffei M, Cohen SL, Chait BT, Rabinowitz D, Lallone RL, Burley SK, Friedman J M. Weight-reducing effects of the plasma protein encoded by the obese gene [See comments]. Science 1995; 269: 543-546.

87. Heinrichs SC, Menzaghi F, Pich EM, Hauger RL, Koob GF. Corticotropin-rel easing factor in the paraventricular nucleus modulates feeding induced by neuropeptide Y. Brain Res 1993; 611: 18-24.

88. Herman J P, Cullinan WE. Neurocircuitry of stress: Central control of the hypothalamopituitary-adrenocortical axis. Trends Neurosci 1997; 20: 78-84.

89. Higgs S, Cooper SJ . Hyperphagia induced by direct administration of midazolam into the parabrachial nucleus of the rat. Eur J Pharmacol 1996; 313: 1-9.

90. Horn CC, Kaplan J M, Grill HJ , Friedman MI. Brain fos-like immunoreactivity in chronic decerebrate and neurologically intact rats given 2,5-anhydro-D-mannitol. Brain Res 1998; 801: 107-115.

91. Huszar D, Lynch CA, Fairchild-Huntress V, Dunmore J H, Fang Q, Berkemeier LR, Gu W, Kesterson RA, Boston BA, Cone RD, Smith FJ , Campfield LA, Burn P, Lee F. Targeted disruption of the melanocortin-4 receptor results in obesity in mice. Cell 1997; 88: 131-141.

92. J acob RJ , Dziura J , Medwick MB, Leone P, Caprio S, During M, Shulman, GI, Sherwin RS. The effect of leptin is enhanced by microinjection into the ventromedial hypothalamus. Diabetes 1997; 46: 150-152.

93. J oseph SA, Michael GJ. Efferent ACTH-IR opiocortin projections from nucleus tractus solitarius: A hypothalamic deafferentation study. Peptides 1988; 9: 193-201.

94. Kalra SP, Dube MG, Sahu A, Phelps CP, Kalra PS. Neuropeptide Y secretion increases in the paraventricular nucleus in association with increased appetite for food. Proc Natl Acad Sci USA 1991; 88: 10931-10935.

95. Kaplan J M, Grill HJ . Swallowing during ongoing fluid ingestion in the rat. Brain Res 1989; 499: $63-80$

96. Kaplan J M, Roitman M, Grill HJ. Food deprivation does not potentiate glucose taste reactivity responses of chronic decerebrate rats. Brain Res 2000; 870: 102-108.

97. Kaplan J M, Siemers W, Grill HJ . Ingestion, gastric fill, and gastric emptying before and after withdrawal of gastric contents. Am J Physiol 1994; 267: R1257-R1265.

98. Kaplan J M, Sodersten P. Apomorphine suppresses ingestive behaviour in chronic decerebrate rats. NeuroReport 1994; 5: 1839-1840.

99. Kaplan J M, Song S, Grill HJ . Serotonin receptors in the caudal brainstem are necessary and sufficient for the anoretic effect of peripherally administered mCPP. Psychopharmacology 1998; 137: 43- 49. 
100. Kaplan J M, Spector AC, Grill HJ . Ingestion rate as an independent variable in the behavioral analysis of satiation. Am J Physiol 1990; 27: R661-R671.

101. Karschin A, Brockhaus J, Ballanyi K. KATP channel formation by the sulphonylurea receptors SUR1 with Kir6.2 subunits in rat dorsal vagal neurons in situ. J Physiol 1998; 509(Pt 2): 339-346.

102. Kask A, Schioth HB. Tonic inhibition of food intake during inactive phase is reversed by the injection of the melanocortin receptor antagonist into the paraventricular nucleus of the hypothalamus and central amygdala of the rat. Brain Res 2000; 887: 460-464.

103. Kelly $A B$, Watts $A G$. The region of the pontine parabrachial nucleus is a major target of dehydration-sensitive $\mathrm{CRH}$ neurons in the rat lateral hypothalamic area. J Comp Neurol 1998; 394: 48- 63.

104. Kennedy GC. The role of depot fat in the hypothal amic control of food intake in the rat. Proc R Soc London Ser B Biol Sci 1953; 140: 578-592.

105. Kotz CM, Glass MJ, Levine AS, Billington CJ . Regional effect of naltrexone in the nucleus of the solitary tract in blockade of NPY-induced feeding. Am J Physiol Regul Integr Comp Physiol 2000; 278: R499-R503.

106. Ladenheim EE, Ritter RC. Low-dose fourth ventricular bombesin selectively suppresses food intake. Am J Physiol 1988; 255: R988-R993.

107. Larsen PJ , Tang-Christensen M, Holst J J , Orskov C. Distribution of glucagon-like peptide-1 and other preproglucagon-derived peptides in the rat hypothalamus and brainstem. Neuroscience 1997; 77: 257-270.

108. Lawrence CB, Turnbull AV, Rothwell NJ. Hypothalamic control of feeding. Curr Opin Neurobiol 1999; 9: 778-783.

109. Legradi G, Lechan RM. The arcuate nucleus is the major source for neuropeptide $Y$ innervation of thyrotropin-rel easing hormone neurons in the hypothalamic paraventricular nucleus. Endocrinology 1998; 139: 3262-3270.

110. Leibowitz SF, Hammer NJ , Chang K. Hypothalamic paraventricular nucleus lesions produce overeating and obesity in the rat. Physiol Behav 1981; 27: 1031-1040.

111. LeMagnen J , Tallon S. La periodicite spontanee de la prise d'aliments ad libiutum du rat blanc. J Physiol 1966; 58: 323-349.

112. Levin BE, Dunn-Meynell AA, Routh VH. Brain glucose sensing and body energy homeostasis: Role in obesity and diabetes. Am J Physiol 1999; 276: R1223-R1231.

113. Li C, Chen P, Smith MS. The acute suckling stimulus induces expression of neuropeptide $Y$ (NPY) in cells in the dorsomedial hypothalamus and increases NPY expression in the arcuate nucleus. Endocrinology 1998; 139: 1645-1652.

114. Li HY, Ericsson A, Sawchenko PE. Distinct mechanisms underlie activation of hypothalamic neurosecretory neurons and their medullary catecholaminergic afferents in categorically different stress paradigms. Proc Natl Acad Sci USA 1996; 93: 2359-2364.

115. Lu D, Willard D, Patel IR, Kadwell S, Overton L, Kost T, Luther M, Chen W, Woychik RP, Wilkison WO, et al. Agouti protein is an antagonist of the melanocyte-stimulating-hormone receptor. Nature 1994; 371: 799- 802.

116. MacDonnell MF, Flynn JP. Control of sensory fields by stimulation of hypothalamus. Science 1966; 152: 1406-1408.

117. Maekawa F, Toyoda Y, Torii N, Miwa I, Thompson RC, Foster DL, Tsukahara S, Tsukamura $\mathrm{H}$, Maeda K. Localization of glucokinase-like immunoreactivity in the rat lower brain stem: For possible location of brain glucose-sensing mechanisms. Endocrinology 2000; 141: 375384.

118. McMahon LR, Wellman PJ . PVN infusion of GLP-1-(7-36) amide suppresses feeding but does not induce aversion or alter locomotion in rats. Am J Physiol 1998; 274: R23-R29.

119. Merali Z, Mcl ntosh J , Anisman H. Role of bombesin-related peptides in the control of food intake. Neuropeptides 1999; 33: 376-386. 
120. Merali Z, Mcl ntosh J, Kent P, Michaud D, Anisman H. Aversive and appetitive events evoke the release of corticotropin-releasing hormone and bombesin-like peptides at the central nucleus of the amygdala. J Neurosci 1998; 18: 4758- 4766.

121. Mercer J G, Moar KM, Hoggard N. Localization of leptin receptor (Ob-R) messenger ribonucleic acid in the rodent hindbrain. Endocrinology 1998; 139: 29-34.

122. Miselis RR, E pstein AN. Feeding induced by intracerebroventicular 2-deoxy-D-glucose in the rat. Am J Physiol 1975; 229: 1438-1447.

123. Mizuno TM, Mobbs CV. Hypothalamic agouti-related protein messenger ribonucleic acid is inhibited by leptin and stimulated by fasting. Endocrinology 1999; 140: 814-817.

124. Mizuno Y, Oomura Y. Glucose responding neurons in the nucleus tractus solitarius of the rat: In vitro study. Brain Res 1984; 307: 109-116.

125. Mook DG, Brandsey SA. Preference-aversion drinking in the rat: The nature of postingestive satiety for sugar solutions. Appetite 1982; 3: 297-307.

126. Morley JE, Levine AS. Corticotrophin releasing factor, grooming and ingestive behavior. Life Sci 1982; 31: 1459-1464.

127. Mountjoy KG, Mortrud MT, Low MJ , Simerly RB, Cone RD. Localization of the melanocortin-4 receptor (MC4-R) in neuroendocrine and autonomic control circuits in the brain. Mol Endocrinol 1994; 8: 1298-1308.

128. Murahashi K, Bucholtz DC, Nagatani S, Tsukahara S, Tsukamura H, Foster DL, Maeda KI. Suppression of luteinizing hormone pulses by restriction of glucose availability is mediated by sensors in the brain stem. Endocrinology 1996; 137: 1171-1176.

129. Nagatani S, Guthikonda P, Thompson RC, Tsukamura H, Maeda KI, Foster DL. Evidence for $\mathrm{GnRH}$ regulation by leptin: Leptin administration prevents reduced pulsatile LH secretion during fasting. Neuroendocrinology 1998; 67: 370-376.

130. Nagatani S, Tsukamura H, Murahashi K, Bucholtz DC, Foster DL, Maeda K. ParaventricuIar norepinephrine release mediates glucoprivic suppression of pulsatile luteinizing hormone secretion. Endocrinology 1996; 137: 3183-3186.

131. Nillni EA, Vaslet C, Harris M, Hollenberg A, Bjorbak C, Flier J S. Leptin regulates prothyrotropin-releasing hormone biosynthesis. Evidence for direct and indirect pathways. J Biol Chem 2000; 275: 36124-36133.

132. Nishiyama M, Makino S, Asaba K, Hashimoto K. Leptin effects on the expression of type-2 $\mathrm{CRH}$ receptor mRNA in the ventromedial hypothalamus in therat. J Neuroendocrinol 1999; 11: 307-314.

133. Norgren R, Pfaffmann C. The pontine taste area in the rat. Brain Res 1975; 91: 99-117.

134. Ohkura S, Tanaka T, Nagatani S, Bucholtz DC, Tsukamura H, Maeda K, Foster DL. Central, but not peripheral, glucose-sensing mechanisms mediate glucoprivic suppression of pulsatile luteinizing hormone secretion in the sheep. Endocrinology 2000; 141: 4472- 4480.

135. Ollmann MM, Wilson BD, Yang YK, Kerns J A, Chen Y, Gantz, I, Barsh GS. Antagonism of central melanocortin receptors in vitro and in vivo by agouti-related protein. Science 1997; 278: $135-138$.

136. Olson BR, Drutarosky MD, Stricker EM, Verbalis J G. Brain oxytocin receptors mediate corticotropin-releasing hormone-induced anorexia. Am J Physiol 1991; 260: R448-R452.

137. Oomura $\mathrm{Y}$, Ono T, Ooyama H, Wayner MJ. Glucose and osmosensitive neurons of the rat hypothalamus. Nature 1969; 222: 282-284.

138. Oomura Y, Ooyama H, Sugimori M, Nakamura T, Yamada Y. Glucose inhibition of the glucose-sensitive neurone in the rat lateral hypothalamus. Nature 1974; 247: 284-286.

139. Pacak K, Palkovits M, Kopin IJ , Goldstein DS. Stress-induced norepinephrine release in the hypothalamic paraventricular nucleus and pituitary-adrenocortical and sympathoadrenal activity: In vivo microdialysis studies. Front Neuroendocrinol 1995; 16: 89-150. 
140. Palkovits M. Interconnections between the neuroendocrine hypothalamus and the central autonomic system. Geoffrey Harris Memorial Lecture, Kitakyushu, J apan, October 1998. Front Neuroendocrinol 1999; 20: 270- 295.

141. Palkovits M, Eskay RL. Distribution and possible origin of $\beta$-endorphin and ACTH in discrete brainstem nuclei of rats. Neuropeptides 1987; 9: 123-137.

142. Polonsky KS, Given BD, Van Cauter E. Twenty-four-hour profiles and pulsatile patterns of insulin secretion in normal and obese subjects. J Clin Invest 1988; 81: 442- 448.

143. Powley TL. The ventromedial hypothalamic syndrome, satiety, and cephalic phase hypothesis. Psychol Rev 1977; 84: 89-126.

144. Reyes TM, Lewis K, Perrin MH, Kunitake KS, Vaughan J , Arias CA, Hogenesch J B, Gulyas J , Rivier J , Vale WW, Sawchenko PE. Urocortin II: A member of the corticotropin-releasing factor (CRF) neuropeptide family that is selectively bound by type 2 CRF receptors. Proc Natl Acad Sci USA 2001; 98: 2843-2848.

145. Richard D. The role of corticotropin-releasing hormone in the regulation of energy balance. Curr Opin Endocrinol Diabetes 1999; 6: 10-18.

146. Ritter RC, Slusser PG, Stone S. Glucoreceptors controlling feeding and blood glucose: Location in the hindbrain. Science 1981; 213: 451- 453.

147. Ritter S, Bugarith K, Dinh TT. Immunotoxic destruction of distinct catecholamine subgroups produces selective impairment of glucor egulatory responses and neuronal activation. J Comp Neurol 2001; 432: 197-216.

148. Ritter S, Dinh TT, Friedman MI. Induction of Fos-like immunoreactivity (Fos-li) and stimulation of feeding by 2,5-anhydro-D-mannitol (2,5-AM) require the vagus nerve. Brain Res 1994; 646: 53- 64.

149. Ritter S, Dinh TT, Zhang Y. Localization of hindbrain glucoreceptive sites controlling food intake and blood glucose. Brain Res 2000; 856: 37- 47.

150. Ritter S, Taylor J S. Vagal sensory neurons are required for lipoprivic but not glucoprivic feeding in rats. Am J Physiol 1990; 258: R1395-R1401.

151. Sahu A, Dube MG, Kalra SP, Kalra PS. Bilateral neural transections at the level of mesencephalon increase food intake and reduce latency to onset of feeding in response to neuropeptide Y. Peptides 1988; 9: 1269-1273.

152. Saper CB. Central autonomic system. In: Paxinos G, Ed. The Rat Nervous System. San Diego: Academic Press, 1995: 107-136.

153. Sawchenko PE. Toward a new neurobiology of energy balance, appetite, and obesity: The anatomists weigh in. J Comp Neurol 1998; 402: 435- 441.

154. Sawchenko PE, Swanson LW, Grzanna R, Howe PR, Bloom SR, Polak J M. Col ocalization of neuropeptide $Y$ immunoreactivity in brainstem catecholaminergic neurons that project to the paraventricular nucleus of the hypothalamus. J Comp Neurol 1985; 241: 138-153.

155. Schneider J E, Zhou D, Blum RM. Leptin and metabolic control of reproduction. Horm Behav 2000; 37: 306-326.

156. Schwartz MW, Seeley RJ, Campfield LA, Burn P, Baskin DG. I dentification of targets of leptin action in rat hypothalamus. J . Clin Invest 1996; 98: 1101-1106.

157. Schwartz MW, Sipols A, Kahn SE, Lattemann DF, Taborsky GJ , J r, Bergman RN, Woods SC, Porte D, J r. Kinetics and specificity of insulin uptake from plasma into cerebrospinal fluid. Am J Physiol 1990; 259: E378-E383.

158. Schwartz MW, Woods SC, Porte D, J r, Seeley RJ, Baskin DG. Central nervous system control of food intake. Nature 2000; 404: 661-671.

159. Sclafani A, Berner CN, Maul G. Multiple knife cuts between the medial and lateral hypothalamus in the rat: A reevaluation of hypothalamic feeding circuitry. J Comp Physiol Psychol 1975; 88: 201-207.

160. Seeley RJ , Grill HJ , Kaplan J M. Neurological dissociation of gastrointestinal and metabolic contributions to meal size control. Behav Neurosci 1994; 108: 347-352. 
161. Seeley RJ , Kaplan J M, Grill HJ . Effects of interrupting an intraoral meal on meal size and meal duration in rats. Appetite 1993; 20: 13-20.

162. Seeley RJ, Matson CA, Chavez M, Woods SC, Dallman MF, Schwartz MW. Behavioral, endocrine, and hypothalamic responses to involuntary overfeeding. AmJ Physiol 1996; 271: R819-R823.

163. Seeley RJ, Payne CJ, Woods SC. Neuropeptide $Y$ fails to increase intraoral intake in rats. Am J Physiol 1995; 268: R423-R427.

164. Seeley RJ, Yagal off KA, Fisher SL, Burn P, Thiele TE, van Dijk G, Baskin DG, Schwartz MW. Melanocortin receptors in leptin effects [Letter]. Nature 1997; 390: 349.

165. Shioda S, Funahashi H, Nakajo S, Yada T, Maruta O, Nakai Y. Immunohistochemical localization of leptin receptor in the rat brain. Neurosci Lett 1998; 243: 41-44.

166. Shiraishi T, Oomura Y, Sasaki K, Wayner MJ. Effects of leptin and orexin-A on food intake and feeding related hypothalamic neurons. Physiol Behav 2000; 71: 251-261.

167. Siemers W, Kaplan J M, Grill HJ . Exogenous insulin increases the rat of gastric emptying after but not during ingestion. Neurosci. Abstr. 1993; 19: 1265.

168. Sladek J R, J r, Sladek CD. Anatomical reciprocity between magnocellular peptides and noradrenaline in putative cardiovascular pathways. Prog Brain Res 1983; 60: 437- 443.

169. Smedh U, Hakansson ML, Meister B, Uvnas-Moberg K. Leptin injected into the fourth ventricle inhibits gastric emptying. NeuroReport 1998; 9: 297-301.

170. Smith GP. The controls of eating: A shift from nutritional homeostasis to behavioral neuroscience. Nutrition 2000; 16: 814- 820.

171. Smith GP, Gibbs J . Postprandial satiety. Prog Psychobiol Physiol Psychol 1979; 8: 179-242.

172. Smith GP, J erome $C$, Norgren R. Afferent axons in abdominal vagus mediate satiety effect of cholecystokinin in rats. Am J Physiol 1985; 249: R638-R641.

173. Smith GP, Schneider LH. Relationships between mesolimbic dopamine function and eating behavior. Ann N Y Acad Sci 1988; 537: 254-261.

174. Spanswick D, Smith MA, Groppi VE, Logan SD, Ashford ML. Leptin inhibits hypothalamic neurons by activation of ATP-sensitive potassium channels. Nature 1997; 390: 521-525.

175. Spanswick D, Smith MA, Mirshamsi S, Routh VH, Ashford ML. Insulin activates ATPsensitive $\mathrm{K}^{+}$channels in hypothalamic neurons of lean, but not obese rats. Nat Neurosci 2000; 3: 757-758.

176. Spector AC, Klumpp PA, Kaplan J M. Analytical issues in the evaluation of food deprivation and sucrose concentration effects on the microstructure of licking behavior in the rat. Behav Neurosci 1998; 112: 678-694.

177. Spina M, Merlo-Pich E, Chan RK, Basso AM, Rivier J, Vale W, Koob GF. Appetitesuppressing effects of urocortin, a CRF-related neuropeptide. Science1996; 273: 1561-1564.

178. Stellar E. The physiology of motivation. Psychol Rev 1954; 61: 5-22.

179. Stricker EM, Rowland NE, Saller CF. Homeostasis during hypoglycemia: Central control of adrenal secretion and peripheral control of feeding. Science 1977; 196: 79-81.

180. Swanson LW, Sawchenko PE, Rivier J, Vale WW. Organization of ovine corticotropinreleasing factor immunoreactive cells and fibers in the rat brain: An immunohistochemical study. Neuroendocrinology 1983; 36: 165-186.

181. Szczypka MS, Rainey MA, Kim DS, Alaynick WA, Marck BT, Matsumoto AM, Palmiter RD. Feeding behavior in dopamine-deficient mice. Proc Natl Acad Sci USA 1999; 96: 1213812143.

182. Tecott LH, Sun LM, Akana SF, Strack AM, Lowenstein DH, Dallman MF, J ulius D. Eating disorder and epilepsy in mice lacking 5- $\mathrm{HT}_{2 \mathrm{C}}$ serotonin receptors. Nature 1995; 374: 542546. 
183. Timofeeva $\mathrm{E}$, Richard D. Functional activation of $\mathrm{CRH}$ neurons and expression of the genes encoding $\mathrm{CRH}$ and its receptors in food-deprived lean ( $\mathrm{Fa} /$ ?) and obese (fa/fa) Zucker rats. Neuroendocrinology 1997; 66: 327-340.

184. Tordoff MG, Rafka R, DiNovi MJ , Friedman MI. 2,5-Anhydro-D-mannitol: A fructose analogue that increases food intake in rats. Am J Physiol 1988; 254: R150-R153.

185. Tordoff MG, Rawson NE, Friedman MI. 2,5-Anhydro-D-mannitol acts in liver to initiate feeding. Am J Physiol 1991; 261: R283-R288.

186. Trapp S, Ashcroft FM. A metabolic sensor in action: News from the ATP-sensitive $\mathrm{K}^{+}$channel. News Physiol Sci 1997; 12: 255-263.

187. Travers J B, DiNardo LA, Karimnamazi H. Motor and premotor mechanisms of licking. Neurosci Biobehav Rev 1997; 21: 631- 647.

188. Uehara Y, Shimizu H, Ohtani K, Sato N, Mori M. Hypothalamic corticotropin-releasing hormone is a mediator of the anorexigenic effect of leptin. Diabetes 1998; 47: 890-893.

189. Unger J W, Moss AM, Livingston J N. I mmunohistochemical localization of insulin receptors and phosphotyrosine in the brainstem of the adult rat. Neuroscience 1991; 42: 853- 861.

190. Vaisse C, Clement K, Durand E, Hercberg S, Guy-Grand B, Froguel P. Melanocortin-4 receptor mutations are a frequent and heterogeneous cause of morbid obesity. J Clin Invest 2000; 106: 253-262.

191. van Dijk G, Bottone AE, Strubbe JH, Steffens AB. Hormonal and metabolic effects of paraventricular hypothalamic administration of neuropeptide $Y$ during rest and feeding. Brain Res 1994; 660: 96-103.

192. van Dijk G, Seeley RJ , Thiele TE, Friedman MI, J i H, Wilkinson CW, Burn, P, Campfield LA, Tenenbaum R, Baskin DG, Woods SC, Schwartz MW. Metabolic, gastrointestinal, and CNS neuropeptide effects of brain leptin administration in the rat. Am J Physiol 1999; 276: R1425-33.

193. van Houten M, Posner BI. Specific binding and internalization of blood-borne [125| ]-iodoinsulin by neurons of the rat area postrema. Endocrinology 1981; 109: 853-859.

194. Verbalis J G, Blackburn RE, Olson BR, Stricker EM. Central oxytocin inhibition of food and salt ingestion: A mechanism for intake regulation of solute homeostasis. Regul Pept 1993; 45: 149-154.

195. Vrang N, Larsen PJ , Kristensen P, Tang-Christensen M. Central administration of cocaineamphetamine-regulated transcript activates hypothalamic neuroendocrine neurons in the rat. Endocrinology 2000; 141: 794-801.

196. Vuagnat BA, Pierroz DD, Lalaoui M, Englaro P, Pralong FP, Blum WF, Aubert ML. Evidence for a leptin-neuropeptide $Y$ axis for the regulation of growth hormone secretion in the rat. Neuroendocrinology 1998; 67: 291-300.

197. Wade GN, Schneider J E, Li HY. Control of fertility by metabolic cues. Am J Physiol 1996; 270: E1-E19.

198. Wang C, Mullet MA, Glass MJ, Billington CJ , Levine AS, Kotz CM. Feeding inhibition by urocortin in the rat hypothalamic paraventricular nucleus. AmJ Physiol Regul Integr Comp Physiol 2001; 280: R473-R480.

199. Williams DL, Kaplan J M, Grill HJ . The role of the dorsal vagal complex and the vagus nerve in feeding effects of melanocortin-3/4 receptor stimulation. Endocrinol ogy 2000; 141: 13321337.

200. Williams G, Harrold J A, Cutler DJ. The hypothalamus and the regulation of energy homeostasis: Lifting the lid on a black box. Proc Nutr Soc 2000; 59: 385-396.

201. Wilson BD, Bagnol D, Kaelin CB, Ollmann M M, Gantz I, Watson SJ , Barsh GS. Physiological and anatomical circuitry between agouti-related protein and leptin signaling. Endocrinology 1999; 140: 2387-2397.

202. Wolgin DL, Oslan IA, Thompson GB. Effects of "anorexia" on appetitive and consummatory behavior. Behav Neurosci 1988; 102: 312-318. 
203. Woods SC, Figlewicz Lattemann DP, Schwartz MW, Porte D, J r. A re-assessment of the regulation of adiposity and appetite by the brain insulin system. Int J Obes 1990; 14(Suppl 3): $69-73$.

204. Woods SC, Seeley RJ, Porte D, J r, Schwartz MW. Signals that regulate food intake and energy homeostasis. Science 1998; 280: 1378-1383.

205. Yettefti K, Orsini J C, Perrin J . Characteristics of glycemia-sensitive neurons in the nucleus tractus solitarii: Possible involvement in nutritional regulation. Physiol Behav 1997; 61: 93-100.

206. Yoshihara T, Honma S, Honma K. Effects of restricted daily feeding on neuropeptide $Y$ release in the rat paraventricular nucleus. Am J Physiol 1996; 270: E589-E595.

207. Young RC, Gibbs J , Antin J, Holt J , Smith GP. Absence of satiety during sham feeding in the rat. J Comp Physiol Psychol 1974; 87: 795- 800.

208. Zhang X, Fogel R, Renehan WE. Stimulation of the paraventricular nucleus modulates the activity of gut-sensitive neurons in the vagal complex. Am J Physiol 1999; 277: G79-G90.

209. Zhang Y, Proenca R, Maffei M, Barone M, Leopold L, Friedman J M. Positional cloning of the mouse obese gene and its human homologue [Published erratum appears in Nature 1995 Mar 30;374(6521):479] [See comments]. Nature 1994; 372: 425- 432.

210. Zhou D, Schneider JE. Fourth ventricular leptin prevents fasting-induced anestrus in hamsters. Soc Neurosci Abstr 1999; 25: 414. 